University of Nebraska - Lincoln

DigitalCommons@University of Nebraska - Lincoln

Papers in the Earth and Atmospheric Sciences

Earth and Atmospheric Sciences, Department

\title{
Sequence stratigraphic controls on synsedimentary cementation and preservation of dinosaur tracks: Example from the lower Cretaceous, (Upper Albian) Dakota Formation, Southeastern Nebraska, U.S.A.
}

Preston Lee Phillips Jr.

University of North Carolina at Pembroke

Greg A. Ludvigson

Kansas Geological Survey, The University of Kansas, Lawrence

R. Matthew Joeckel

University of Nebraska-Lincoln, rjoeckel3@unl.edu

Luis A. González

The University of Kansas, Lawrence

Robert L. Brenner

University of lowa

See next page for additional authors

Follow this and additional works at: https://digitalcommons.unl.edu/geosciencefacpub

Part of the Earth Sciences Commons

Phillips, Preston Lee Jr.; Ludvigson, Greg A.; Joeckel, R. Matthew; González, Luis A.; Brenner, Robert L.; and Witzke, Brian J., "Sequence stratigraphic controls on synsedimentary cementation and preservation of dinosaur tracks: Example from the lower Cretaceous, (Upper Albian) Dakota Formation, Southeastern Nebraska, U.S.A." (2007). Papers in the Earth and Atmospheric Sciences. 297.

https://digitalcommons.unl.edu/geosciencefacpub/297

This Article is brought to you for free and open access by the Earth and Atmospheric Sciences, Department of at DigitalCommons@University of Nebraska - Lincoln. It has been accepted for inclusion in Papers in the Earth and Atmospheric Sciences by an authorized administrator of DigitalCommons@University of Nebraska - Lincoln. 


\section{Authors}

Preston Lee Phillips Jr., Greg A. Ludvigson, R. Matthew Joeckel, Luis A. González, Robert L. Brenner, and Brian J. Witzke 


\title{
Sequence stratigraphic controls on synsedimentary cementation and preservation of dinosaur tracks: Example from the lower Cretaceous, (Upper Albian) Dakota Formation, Southeastern Nebraska, U.S.A.
}

\author{
Preston Lee Phillips Jr., ${ }^{1}$ Greg A. Ludvigson,, ${ }^{2}$ R. Matthew Joeckel, ${ }^{3}$ \\ Luis A. González, ${ }^{4}$ Robert L. Brenner, ${ }^{5}$ and Brian J. Witzke ${ }^{5,6}$ \\ 1. Department of Geology and Geography, The University of North Carolina at Pembroke, \\ Pembroke, NC 28372-1510, USA \\ 2. Kansas Geological Survey, The University of Kansas, Lawrence, KS 66047-3726, USA \\ 3. Conservation and Survey Division, School of Natural Resources, University of \\ Nebraska-Lincoln, Lincoln, Nebraska 68583-0996, USA \\ 4. Department of Geology, The University of Kansas, Lawrence, KS 66045-7613, USA \\ 5. Department of Geoscience, The University of Iowa, Iowa City, IA 52242-1379, USA \\ 6. Iowa Department of Natural Resources, Geological Survey, Iowa City, IA 52242-1319, \\ USA \\ Corresponding author - P. L. Phillips, tel 910 522-5787, fax 910 521-6606, email lee.phillips@uncp.edu
}

\begin{abstract}
A thin cemented sandstone bed in the Upper Albian Dakota Formation of southeastern Nebraska contains the first dinosaur tracks to be described from the state. Of equal importance to the tracks are stable-isotope (C, O) analyses of cements in the track bed, especially in the context of data derived from generally correlative strata (sandstones and sphaerosiderite-bearing paleosols) in the region. These data provide the framework for interpretations of paleoenvironmental conditions, as well as a novel approach to understanding mechanisms of terrestrial vertebrate track preservation.

High minus-cement-porosity $(>47 \%)$ and low grain-to-grain contacts $(\sim 2.5)$ in the track bed indicate early (pre-compaction) lithification. Although phreatic cements dominate, the history of cementation within this stratigraphic interval is complex. Cathodoluminescence petrography reveals two distinct calcite zones in the track-bearing horizon and four cement zones in stratigraphically equivalent strata from a nearby section. The earliest calcite cements from both localities are likely coeval because they exhibit identical positive covariant trends $\left(\delta^{18} \mathrm{O}\right.$ values of -9.89 to $-6.32 \%$ and $\delta^{13} \mathrm{C}$ values of -28.01 to $-19.33 \%$ VPDB $)$ and record mixing of brackish and meteoric groundwaters. All other calcite cements define meteoric calcite lines with $\delta^{18} \mathrm{O}$ values clustering around $-9.42 \%$ and $-8.21 \%$ VPDB from the track-bearing horizon, and $-7.74 \%$, $-5.81 \%$, and $-3.95 \%$ VPDB from the neighboring section. Distinct meteoric sphaerosiderite lines from roughly correlative paleosols serve as a proxy for locally recharged groundwaters. Back-calculated paleogroundwater $\delta^{18} \mathrm{O}$ estimates from paleosol sphaerosiderites range from -7.4 to $-4.2 \%$ o SMOW; whereas, meteoric calcite lines from the track horizon are generally more depleted.

Differences in cement $\delta^{18} \mathrm{O}$ values record changes in paleogroundwater recharge areas over time. Early calcite cements indicate mixing of fresh and brackish groundwaters during the syndepositional lithification of the track horizon. Later calcite cements, however, indicate recharge from a larger catchment basin that extended far inland. Therefore, the cements likely record a rise and subsequent fall in relative sea level. We conclude that scrutiny of the cement isotope geochemistry of genetically significant surfaces, especially track beds, can provide new data for interpreting sea level change.
\end{abstract}

Keywords: Cretaceous, diagenesis, isotopes, dinosaur tracks, carbonate cements 


\section{Introduction}

The preservation of fossils of vertebrate and invertebrate organisms and of their traces provides a window to Earth's past ecosystems. Among some of the most spectacular traces of large vertebrates (e.g. dinosaurs) are large arrays of footprints of numerous individuals of the same or different species that are collectively called "tracksites." During the past decade, numerous studies have suggested that the preservation of dinosaur tracks may be, in part, controlled by relative sea level rise (e.g. Lockley et al., 1992, 2006; Lockley and Hunt, 1995; Matsukawa et al., 1999; Kurtz et al., 2001; Kvale et al., 2001). Lockley and Hunt (1995) noted similarities in stratigraphic positioning of track beds/intervals (megatracksites) within the Upper Triassic Chinle Group (Utah, New Mexico, Texas, Oklahoma, Colorado, Arizona, and Wyoming) and the Lower Cretaceous Dakota Group
(Colorado and New Mexico). In fact, hundreds of ornithopod tracks have been described from numerous Dakota Group exposures in the Colorado - New Mexico Rocky Mountain Front Range - High Plains area. Lockley et al. (1992, p. 50) observed that track-bearing intervals are common within aggradational deposits "associated with lowstand through early transgressive phase deposits." Furthermore, they noted that such depositional conditions are optimal for track formation and preservation due to relatively high water tables. These Late Albian dinosaur trackways all occur within a narrow stratigraphic interval and have been placed at or near Weimer's (1988) sequence 3 boundary (within the Muddy Formation or J Sandstone) of the Dakota Group (Figure 1) (Lockley et al., 1992; Matsukawa et al., 1999). However, Lucas et al. (2000) argued against these conclusions, claiming that stratigraphy of megatracksite occurrences are not well understood.

REGIONAL STRATIGRAPHY

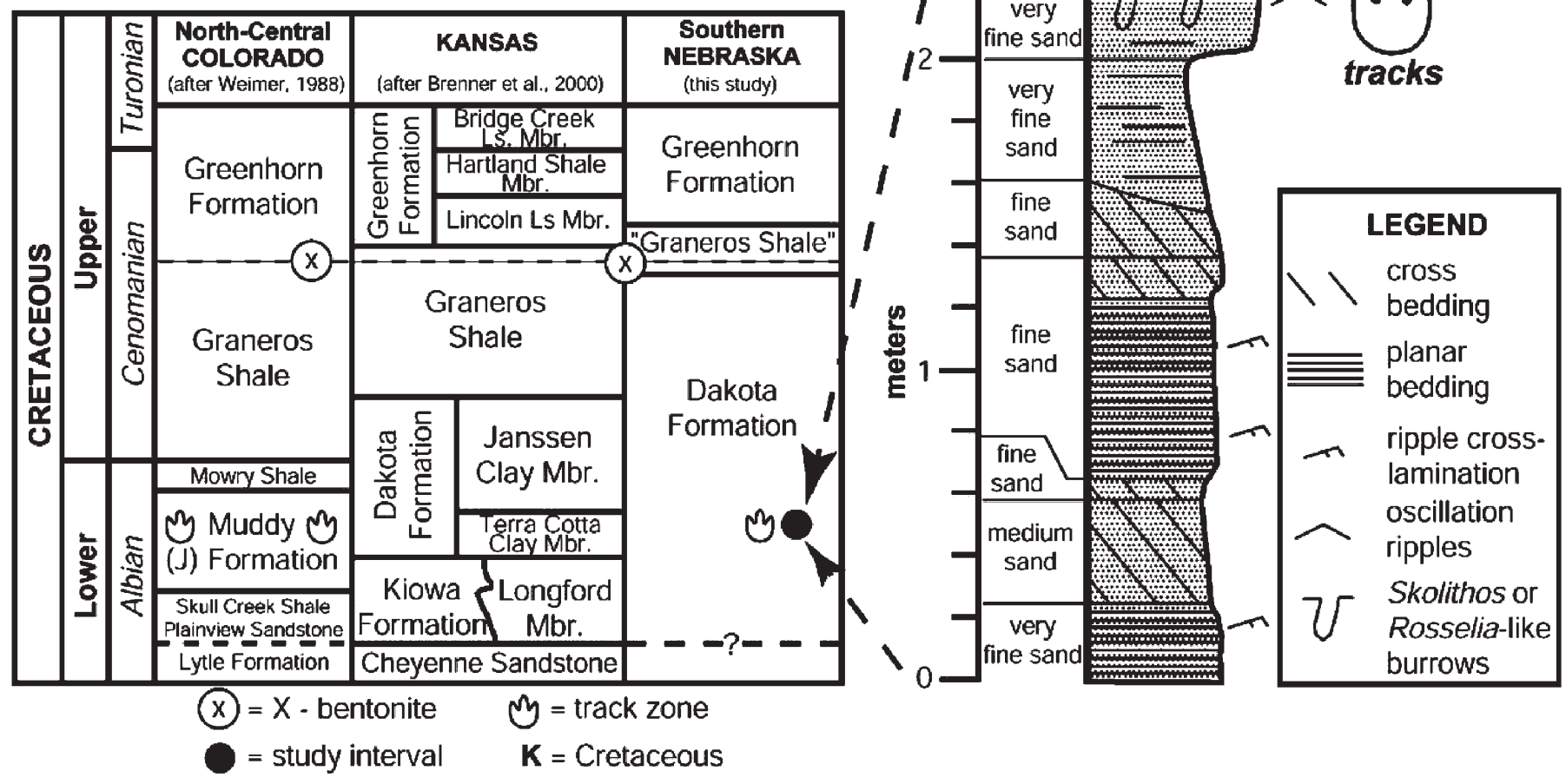

Figure 1. Chart showing the stratigraphic nomenclature of Albian and Cenomanian strata in the study area and their correlation to strata in north-central Colorado. This figure is modified after Joeckel et al. (2004). A detailed stratigraphic column of the measured outcrop section at the dinosaur tracksite is included. Column profile approximates weathering profile. Note that the measured section corresponds to a single point within the upper Albian portion of the Dakota Formation of southern Nebraska. These strata are correlative to Muddy Cycle deposits of Kansas and Colorado. 
Most tracks identified within the stratigraphic record are set in once-soft sediments that were situated at or near the paleo-watertable (e.g. Lockley et al., 1992). The environmental associations of sediments at or near a watertable are limited to riverine, lacustrine, wetland, and coastal reaches. The potential track-bearing strata require the addition of sediment over the imprinted surface to assist in long-term preservation. In coastal areas additional sediment accumulation can result from many depositional processes that are largely controlled by relative shifts in paleo-shoreline position. Even so, preservation of track horizons is complicated by natural sedimentological events (discussed in the following section) and requires lithification to ensure their preservation in the geologic record. Lithification of coastal sandstone/ siltstone deposits can be achieved by the precipitation of carbonate cements within pore spaces of the strata. Taylor et al. (2000, p. 362) noted preferential sheetlike cementation of strata "exclusively beneath marine flooding surfaces." They proposed that cementation at sequence boundaries was initiated by marine transgression and continued through the sediment burial process.

This study is based on Upper Albian sedimentary units deposited along the eastern margin of the Cretaceous Western Interior Seaway that contain the first reported dinosaur tracks (Joeckel et al., 2004) within the Dakota Formation in the Iowa-Nebraska region (Figures $1-3)$. The purpose of this paper is to (1) improve our un-

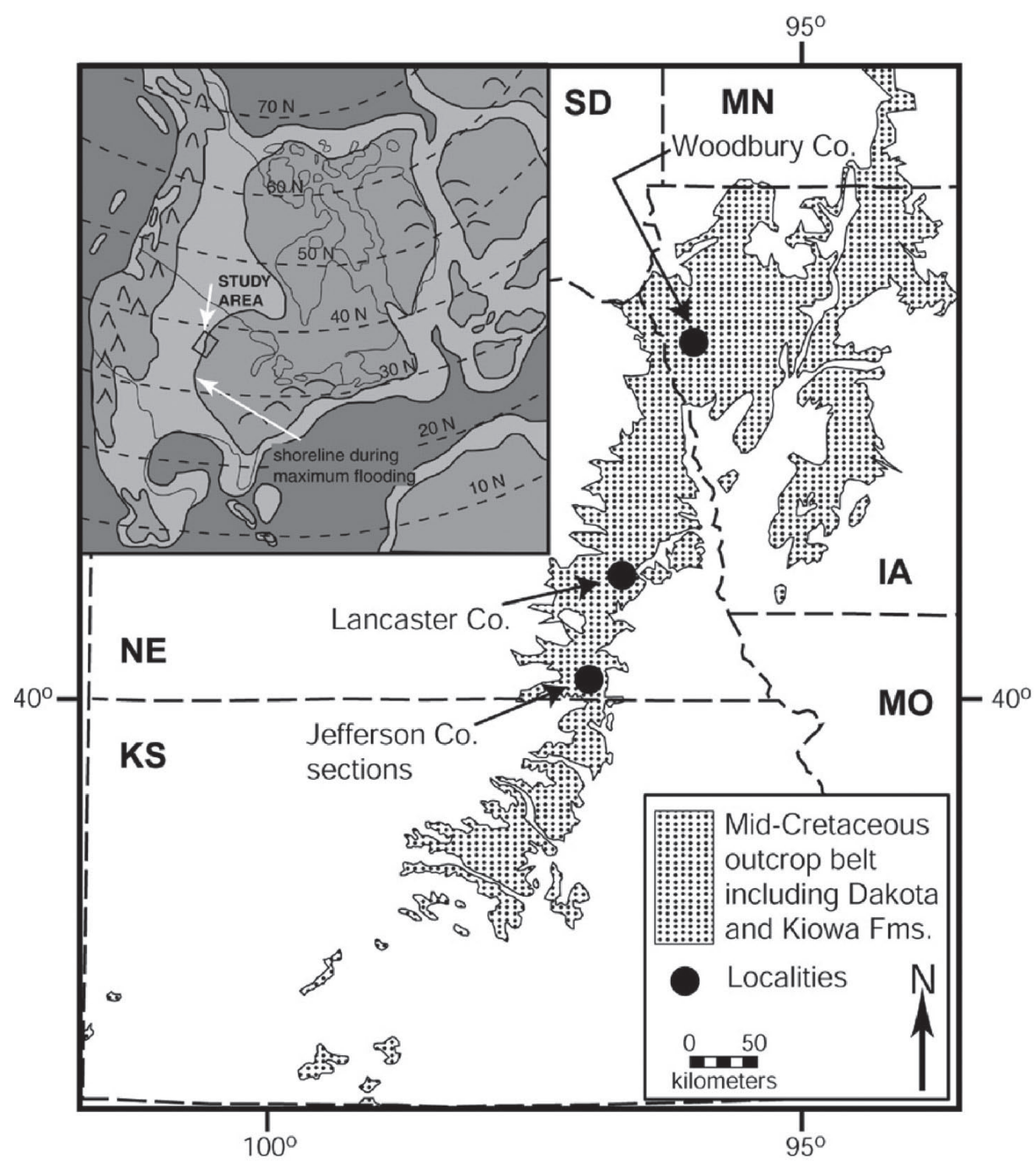

Figure 2. Map showing the location of outcrop and cored sections within the context of the Dakota Formation outcrop belt, modified from Witzke and Ludvigson (1994). Map inset shows the study area within the context of a Late Albian paleogeographic reconstruction at near-maximum sea level highstand. 


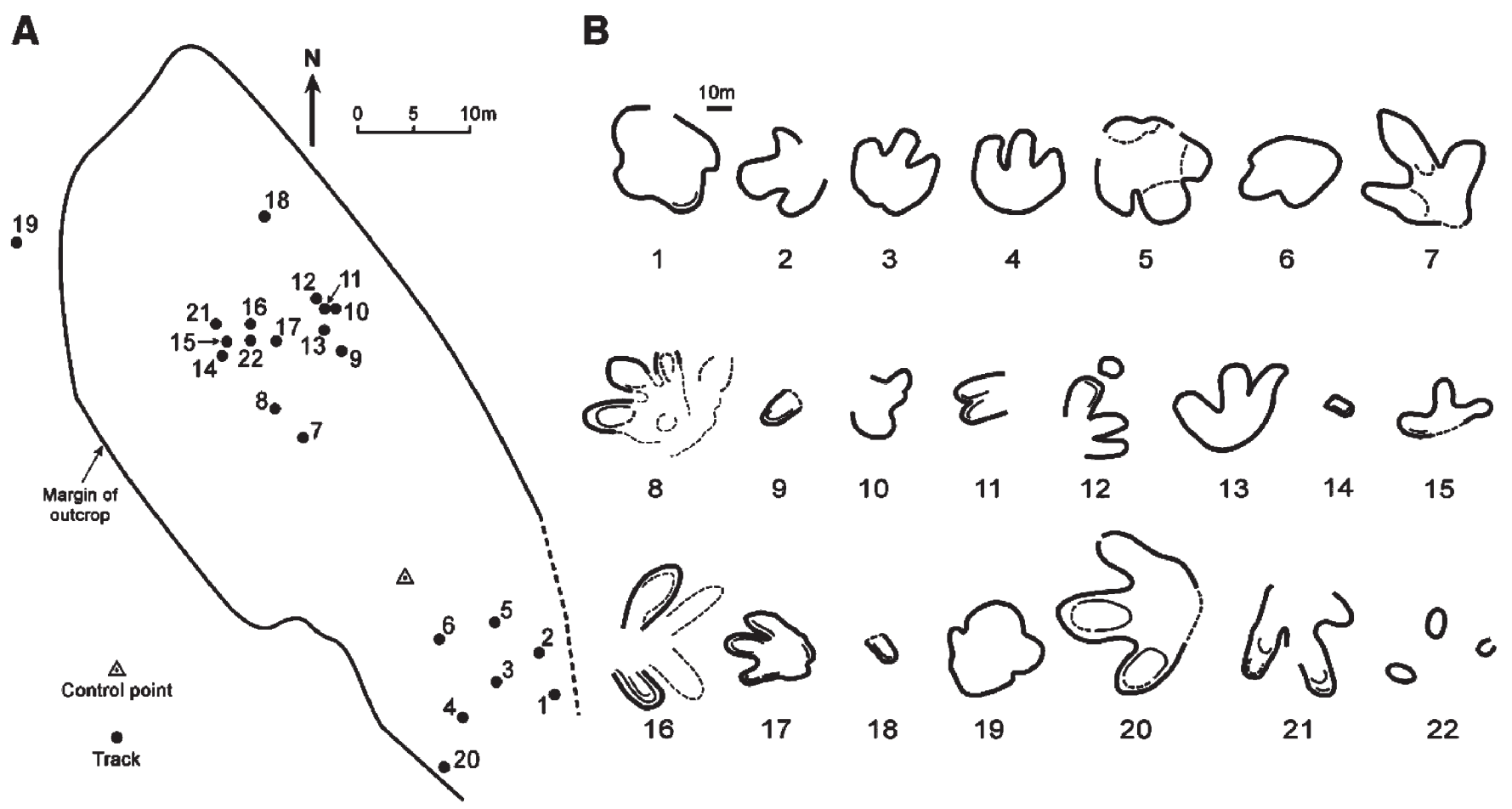

Figure 3. A) Sketch of the tracksite, a flat-topped sandstone bench, showing the distribution of tracks. B) Outline sketches of individual tracks, most likely deposited by ornithopods. (From Joeckel et al., 2004)

derstanding of how tracks are preserved and (2) investigate a track occurrence in association with an exposure surface that was deposited close to sea-level and was rapidly cemented under conditions of rising base-level. We propose that track preservation at this locality was achieved, in part, by precipitation of early diagenetic cements whose chemistry records important paleoenvironmental/paleoclimatic information. To better understand the paleogroundwater environments of this area, the stable oxygen and carbon isotopic compositions of early diagenetic calcite cements in the track-bearing horizon were determined. These data are compared with pedogenic sphaerosiderite nodules from coeval paleosols collected from Lancaster County, Nebraska, as well as paleosol sphaerosiderite data reported by Ludvigson et al. (1998) from Woodbury County, Iowa (Figure 2 ), which serve as a proxy for local paleoprecipitation (Ludvigson et al., 1998). In this paper, we provide estimates of the $\delta^{18} \mathrm{O}$ composition of the groundwaters from which these cement phases precipitated. Additionally, we present arguments that the track-bearing horizon is a stratigraphically-significant surface, marking the position of a marine flooding surface within the Muddy Cycle of the Cretaceous Western Interior Basin.

\section{Track preservation models}

The preservation of individual footprints, and more so of tracksites, is rare because subsequent erosional and deformation events (e.g. rooting, bioturbation, burial deformation) can completely obliterate these typically ephemeral traces of life. Multiple scenarios have been proposed to favor the preservation of tracks in the stratigraphic record (Gillette and Lockley, 1989; Lockley and Hunt, 1995; Lockley and Peterson, 2002). The most commonly invoked scenario, and possibly the rarest, proposes that tracks were imprinted on a wet substrate and subsequently desiccated until hardened, thus becoming resistant to erosive events (Lockley, 1989). Rare "true tracks," as they are called, commonly preserve skin impressions and/or mudcracks (e.g. Lockley, 1988; Paik et al., 2001). Lockley and Peterson (2002) use the term "cover up" to describe the emplacement of true tracks. Other sites preserve tracks that appear to be deep imprints resulting from heavy animals traveling across the substrate, where the actual surficial imprints ("true-tracks") are not preserved. These "deep prints" are preserved because they were not exposed to destructive earth surface processes and were never subjected to significant pedogenic modification (e.g. Kurtz et al., 2001; Paik et al., 2001). Lockley and Peterson (2002) use the term "direct deposit" to describe the emplacement of deep prints. Still, other track sites seem to exhibit preservation characteristics consistent with deep footprints acting as a shelter from erosive currents and a trap for sediments in transport (e.g. Lockley, 1991; Jenkins et al., 1994; Gatesy et al., 1999; Paik et al., 2001). The commonality of these three scenarios is that all track-bearing horizons were 


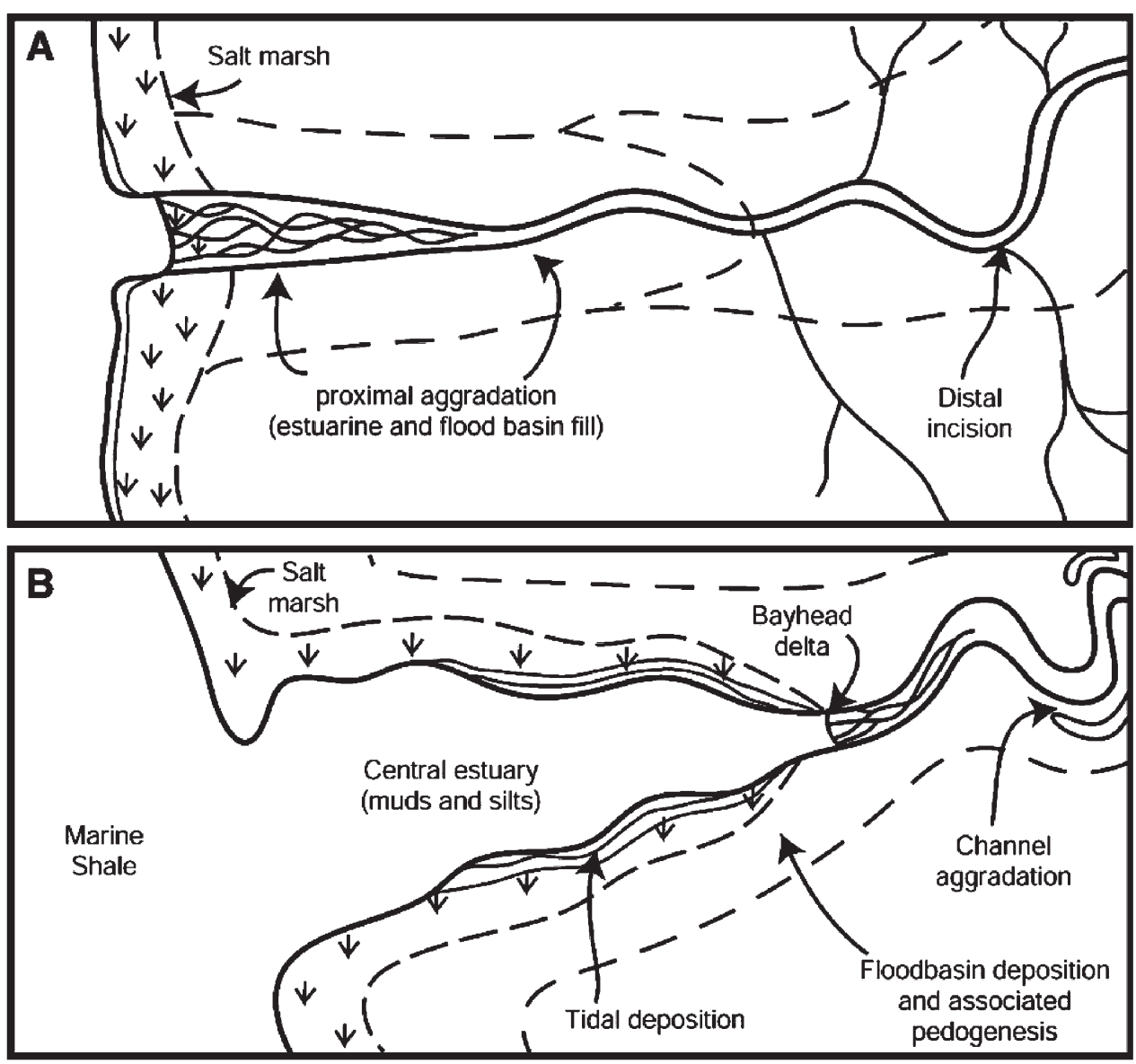

Figure 4. Schematic illustration of an estuarine setting during marine offlap (A) and marine onlap (B). A) During a relative drop in sea level, the coastal valley is filled with coarser sediments due to progradation of distributary channels. Channel incision is likely to occur higher in the system. Such incision recycles sediments deposited in prior flooding events. B) At times of marine inundation of coastal valleys, muds and silts are deposited in the estuarine bay portion of the system and can be typified by carbonaceous shales and/or mudstones, which can contain marine palynomorphs and pyrite. Deposition of coarse sediments is limited to upper reaches of the estuary, in the bayhead delta and upstream regions. Upstream portion of the system is typified by channel aggradation.

lithified in a manner that prevented track obliteration and deformation during subsequent burial. Thus, it is early lithification, i.e. prior to burial deformation, that is an important additional mode of track preservation that has been insufficiently studied.

\section{Geological setting and study area}

The Albian-Cenomanian Dakota Formation of the eastern margin of the Cretaceous Western Interior Seaway was deposited as part of a complex of lowsinuosity braided stream and meander belts in a fluvial-estuarine depositional environment (Whitley, 1980; Whitley and Brenner, 1981; Munter et al., 1983; Witzke et al., 1983) (Figure 4). Proximal fluvial strata of the Dakota Formation are interpreted to have been deposited within a series of incised valleys, while the distal deposits likely accumulated in a near-shore marine environment (Brenner et al., 2000). The east- ern margin of the Cretaceous Western Interior Seaway was the stable cratonic margin of a foreland basin (Figure 2, inset). Strata deposited along the stable cratonic margin were less subject to tectonic activity (e.g. local and regional tectono-eustasy, folding and faulting, pressure-induced diagenesis) than those of the orogenic margin.

The Dakota Formation includes a lower sandstonedominated Nishnabotna Member and a mudstonedominated upper Woodbury Member (Whitley, 1980; Whitley and Brenner, 1981; Munter et al., 1983; Witzke et al., 1983). In Iowa and Nebraska, the Nishnabotna Member rests unconformably on Pennsylvanian and older Paleozoic strata. The Woodbury Member is overlain by the marine "Graneros Shale" where it has not been removed by post-Cretaceous erosion. In Kansas, the Dakota Formation conformably to disconformably overlies the Kiowa Formation, and is overlain by the Graneros Shale (Plummer and Romary, 1942; Hamilton, 1994) (Figure 1). 


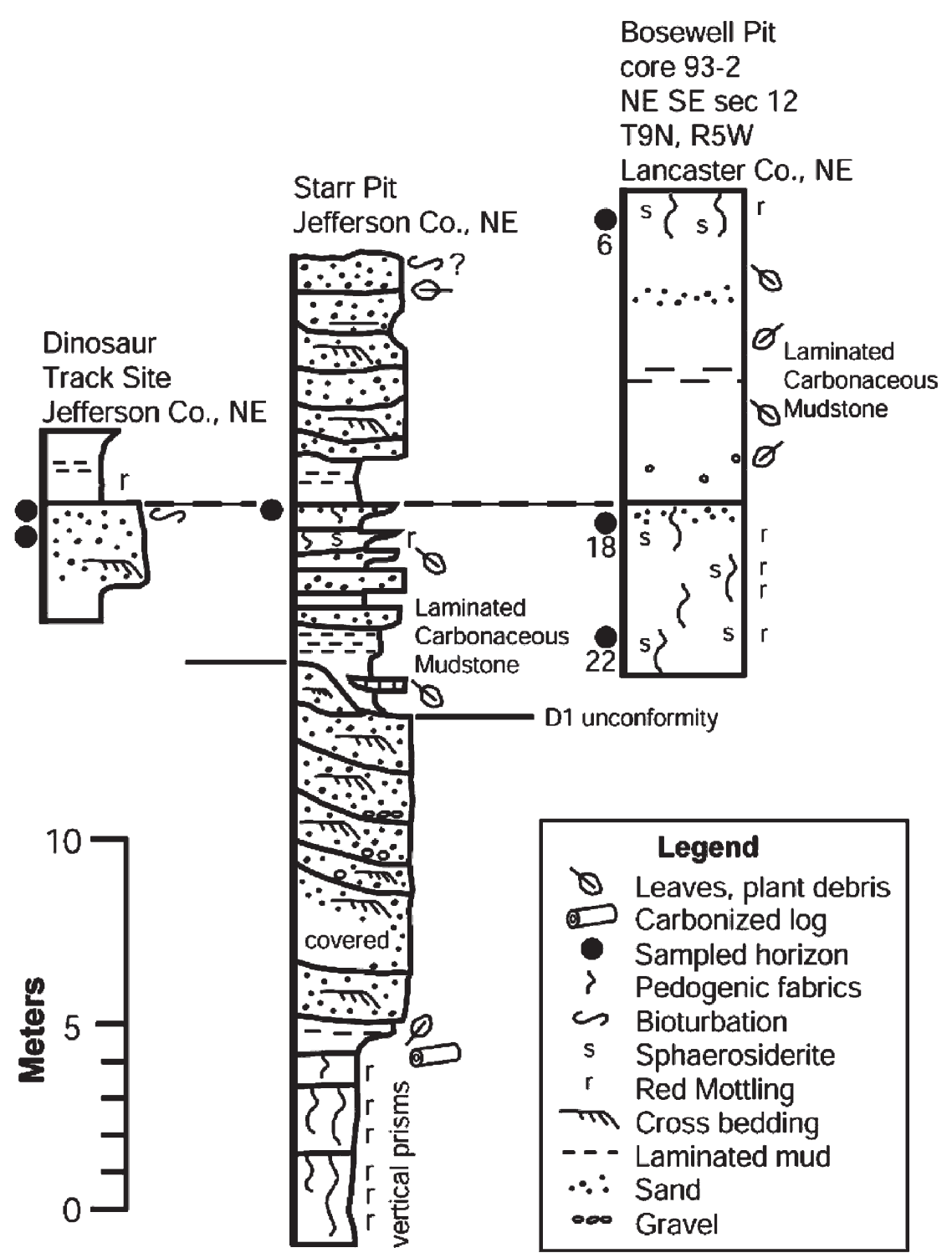

Figure 5. Stratigraphic columns of Dakota Formation lithologies in the study area. The bold dashed line between the sections shows the interpreted correlation of this significant horizon based on lithostratigraphy and palynomorph biostratigraphy. The bold solid line next to the Starr Pit section denotes the boundary between the Kiowa-Skull Creek and Muddy Cycles (as proposed by Brenner et al., 2000).

The study areas include the dinosaur tracksite reported by Joeckel et al. (2004) and an equivalent horizon within the Starr Pit sand quarry located $8 \mathrm{~km}$ northeast of the tracksite. Both are located on private property in Jefferson County, Nebraska, U.S.A. (Figures 1, 2, \& 5). Due to privacy concerns of the landowners, exact locations are not disclosed. Supplemental to the primary study area are approximately coeval strata cored from the Bosewell Pit of the Yankee Hill Brick and Tile properties in Lancaster County, Nebraska (Figures 2 \& 5). Comparative data are from multiple outcrops and cored sections within the depositional extent of the Dakota Formation in the Iowa, Kansas, Minnesota, and Nebraska region (Figure 2).
Dakota Formation lithologies at the Starr Pit and Bosewell Pit sections were part of a regional study that identified three depositional cycles within the Dakota Formation (Brenner et al., 2000). Temporal control of the Dakota Formation along the eastern margin of the Cretaceous Western Interior Seaway is largely determined by the interfingering relationship of nonmarine strata with marine facies, where molluscan and foraminiferal biozonations are coupled with ash radiochronology. Terrestrial strata have been subdivided into palynostratigraphic units, which are largely coincident with marine cycles of the Western Interior Seaway (Ravn and Witzke, 1995) (Table 1). The horizons sampled as part of this study are situated approximately $5 \mathrm{~m}$ above the 
Table 1. Terrestrial palynostratigraphic correlation. Identifications by Robert Ravn

\begin{tabular}{|c|c|c|}
\hline Timing & Marine cycle & Palynomorphs (abbreviated list) \\
\hline $\begin{array}{l}\text { early } \\
\text { Late Albian }\end{array}$ & $\begin{array}{l}\text { Kiowa-Skull } \\
\text { Creek }\end{array}$ & $\begin{array}{l}\text { Disaltriangulisporites perplexus } \\
\text { Eucommidites minor } \\
\text { Foveosporites labiosus }\end{array}$ \\
\hline $\begin{array}{l}\text { late } \\
\text { Late Albian }\end{array}$ & Muddy & $\begin{array}{l}\text { Cedripites canadensis } \\
\text { Plicatella jansonii } \\
\text { Podocarpidites multiesimus } \\
\text { Vitreisporites pallidus }\end{array}$ \\
\hline $\begin{array}{l}\text { Early } \\
\text { Cenomanian }\end{array}$ & $\begin{array}{l}\text { Basal } \\
\text { Greenhorn }\end{array}$ & $\begin{array}{l}\text { Balmeisporites glenelgensis } \\
\text { Foveosporites cenomanianus } \\
\text { Petalosporites quadrangulatus } \\
\text { Triporoletes pluricellulus* } \\
\text { Neoraistrickia robusta* } \\
\quad=\text { last appearance }\end{array}$ \\
\hline $\begin{array}{l}\text { Middle } \\
\text { Cenomanian }\end{array}$ & $\begin{array}{l}\text { Upper } \\
\text { Greenhorn }\end{array}$ & $\begin{array}{l}\text { Cicatricosisporites crassiterminatus } \\
\text { Dictyophyllidites impensus } \\
\text { Foveogleicheniidites confossus } \\
\text { Lycopodiacidites arcuatus } \\
\text { Montipollis hallii }\end{array}$ \\
\hline
\end{tabular}

“ $\mathrm{D}_{1}$ " unconformity identified by Brenner et al. (2000) and are interpreted to be part of the Muddy Cycle (sensu Scott et al., 1998) or the "J Sequence" of Hamilton (1994). The Muddy Cycle followed the Kiowa-Skull Creek Cycle, recognized by estuarine and fluvial deposits that extend hundreds of kilometers from the seaway edge into central Iowa. Similarly, there was a lower amplitude landward shift of estuarine and fluvial facies during the Muddy Cycle that extended into eastern Nebraska and western Iowa. Transgression of the Cretaceous Western Interior Seaway is documented by marine palynomorphs recovered from carbonaceous shales and mudstones interbedded with fluvial/estuarine sandstone deposits (Table 2). A study by Young (2002) on mid-Cretaceous strata along the eastern margin of the Western Interior Seaway identified eight fluvial-estuarine parasequences within Muddy Cycle deposits delineated by marine flooding surfaces, which are marked by mudstones with high hydrogen indices (HI) values.

\section{Methods}

Samples were collected from the track level and $0.5 \mathrm{~m}$ below the surface on which the dinosaur tracks are found. Additional samples were collected from stratigraphically equivalent strata within the Starr Pit sand quarry. Specimens were stabilized by vacuum injection of blue-dyed epoxy resin and serially sectioned perpendicular to bedding. One slab was thin-sectioned and the corresponding thin-slab was polished for micro-sampling. Diagenetic histories of the Dakota Formation sandstones at these localities were evaluated using standard petrographic techniques, including polarized light microscopy and cathodoluminescence (CL) petrography.
Table 2. Marine Palynomorphs from the Dakota Formation in the Kansas-Nebraska region

\begin{tabular}{|c|c|c|c|c|c|}
\hline TAXON & 1 & 2 & 3 & 4 & 5 \\
\hline Achomosphaera? sp. & $x$ & & & & $x$ \\
\hline Apteodinium sp. & $X$ & & & & $x$ \\
\hline Ascodinium sp. & $x$ & & & & $x$ \\
\hline Baltisphaeridium sp. & & $x$ & $x$ & & \\
\hline Circulodinium distinctum & $x$ & & $x$ & & \\
\hline Chlamydophorella sp. cf. C. discreta & $x$ & & & & $x$ \\
\hline C? sp. & & $x$ & & & $x$ \\
\hline Cometodinium sp. cf. C. whitei & $x$ & & & & $x$ \\
\hline Coronifera oceanica & $x$ & & & & $x$ \\
\hline Cribroperidinium spp. & $x$ & & $?$ & $x$ & $x$ \\
\hline Cyclonephelium sp. cf. C. compactum & $x$ & & & & $x$ \\
\hline Cymatiosphaera sp. & & $x$ & & $x$ & \\
\hline cf. Dinopterygium cladoides & $x$ & & & $x$ & $x$ \\
\hline Exochosphaeridium? sp. & $x$ & & & & $x$ \\
\hline indet. gonyaulacoid dinocyst & & $x$ & & & $x$ \\
\hline cf. Gorgonisphaeridium sp. & & $X$ & & $x$ & \\
\hline Heterosphaeridium difficile & $x$ & & & & $x$ \\
\hline Hystrichondinium pulchrum & $x$ & $x$ & & & $x$ \\
\hline Impletosphaderidium spp. & $x$ & $x$ & $x$ & $?$ & $x$ \\
\hline Kiokansium sp. & $x$ & & & & $x$ \\
\hline Leiosphaeridia sp. & & $x$ & & $x$ & $x$ \\
\hline indet. leiosphere spp. & & $x$ & & & $x$ \\
\hline cf. Lophosphaeridium sp. & & $x$ & & & $x$ \\
\hline Michystridium spp. & $x$ & $x$ & $x$ & $x$ & $x$ \\
\hline Multiplicisphaeridium sp. & $x$ & & $x$ & & \\
\hline Odontochitina operculata & $x$ & $x$ & & $x$ & $x$ \\
\hline O. rhakodes & $x$ & & & & $x$ \\
\hline Oligosphaeridium complex & $x$ & & & & $x$ \\
\hline Oligosphaeridium pulcherrimum & $x$ & & & $x$ & \\
\hline Palaeoperidinium cretaceum & $x$ & & & & $x$ \\
\hline indet. ?pilomate cyst & & $x$ & & $x$ & \\
\hline Pterospermella sp. cf. P. hartii & $x$ & & & & $x$ \\
\hline P. sp. & $x$ & & & & $x$ \\
\hline Senoniasphaera sp. & $x$ & & & & $x$ \\
\hline indet. skolochorate dinocyst & & $x$ & $x$ & $x$ & $x$ \\
\hline Spiniferites sp. & $x$ & & & & $x$ \\
\hline Subtilisphaera sp. & $x$ & & & & $x$ \\
\hline ?Systematophora sp. & $x$ & $x$ & & & $x$ \\
\hline ?Trichodinium sp. & $x$ & & & & $x$ \\
\hline Veryhachium sp. & $x$ & $x$ & $x$ & $x$ & $x$ \\
\hline Xiphophoridium alatum & $x$ & & & & $x$ \\
\hline indet. angular dinocyst & & $x$ & & & $x$ \\
\hline indet. alate spinose dinocyst & & $x$ & & & $x$ \\
\hline
\end{tabular}

Identifications by Robert Ravn: 1. Kansas; 2. Nebraska; 3. Lower Greenhorn Cycle; 4. Muddy Cycle; 5. Kiowa-Skull Creek Marine Cycle; $?=$ probable identification.

Relative abundance of rock constituent components was determined by modal analyses of 300 point counts. The data were normalized to $100 \%$ using three framework grain categories (quartz, feldspar, and rock fragments), which were plotted as end-members on a ternary diagram. Herein, quartz grains are reported in their normalized percentage. The sandstones of the Dakota Formation were classified using Folk's (1968) scheme for sandstones. Individual cement zones identified by luminescence characteristics were milled using a microscope-mounted drill assembly with a $0.5 \mathrm{~mm}$-diameter tungsten carbide bit. 
Sphaerosiderite nodules were washed and screened from three paleosol horizons identified within the Bosewell Pit core (93-2), Yankee Hill Brick and Tile properties, Lancaster County, Nebraska (Figures 2 \& 5). Thin sections and corresponding thin slabs were prepared from sphaerosiderites mounted in epoxy plugs for petrographic analyses and micro-sampling efforts, respectively. Thin sections were evaluated to ensure that only pristine siderite was sampled. Individual sphaerosiderite nodules were milled using a microscope-mounted drill assembly with a $0.5 \mathrm{~mm}$-diameter tungsten carbide bit.

Powdered microsamples ( 0.1 to $0.2 \mathrm{mg}$ ) were roasted in vacuum at $380^{\circ} \mathrm{C}$ for $1 \mathrm{~h}$ to remove volatile contaminants. Powders were then reacted with anhydrous phosphoric acid at $75^{\circ} \mathrm{C}$ in a Kiel III carbonate reaction device coupled to the inlet of a Finnigan MAT 252 gas ratio mass spectrometer in the University of Iowa Paul $\mathrm{H}$. Nelson Stable Isotope Laboratory. Samples from the Yankee Hill clay pit were analyzed on a Kiel I carbonate reaction device coupled to the inlet of a Finnigan MAT 251 gas ratio mass spectrometer in the University of Michigan Stable Isotope Laboratory. All isotopic data are reported in standard delta $(\delta)$ notation with values relative to the VPDB standard. Siderite oxygen isotopic data were corrected for the temperature-dependent fractionation between phosphoric acid and siderite using the experimental data of Carothers et al. (1988). Daily analyses of interlaboratory standards show a precision of better than $\pm 0.05 \%$ o for both carbon and oxygen isotopes. Isotopic data $\left(\delta^{18} \mathrm{O}\right)$ generated for this study were coupled with paleobotanical paleotemperature estimates (Wolfe and Upchurch, 1987) to estimate the isotopic compositions of groundwaters from which the cements precipitated.

\section{Results}

\subsection{Lithofacies description}

The Dakota Formation in the study area is characterized by six lithofacies: (1) sphaerosiderite-bearing blocky mudstone, (2) laminated clay and silty mudstone/shale, (3) mottled ripple-laminated/horizontally bedded sandstone, (4) ripple cross-laminated sandstone (5) horizontally-bedded sandstone, and (6) tabular cross-bedded sandstone (Table 3).

\subsubsection{Sphaerosiderite-bearing blocky mudstone}

The mudstone occurrences in this lithofacies are variable in texture and color. Exploration cores from the Bosewell Pit provided access to intervals of clayey mudstone that exhibit a range of colors from light gray to red. Each of these mudstone intervals contains milli- meter-scale sphaerosiderite nodules that display radial concentric forms. These nodules commonly have pyrite cubes in their cores, and they occur most commonly as individual nodules, but are also observed as clusters and arrays of nodules. Sphaerosiderite nodules range from 0.2 to $0.7 \mathrm{~mm}$ diameter as individual nodules and up to $1.6 \mathrm{~mm}$ long arrays (Figure $6 \mathrm{H}$ ). This lithofacies in the Starr Pit consists of gray-green to light gray mudstone that contains silty lenses with $\mathrm{mm}$-scale spheroidal iron oxides.

\subsubsection{Laminated clay and silty mudstone/shale}

The laminated mudstone lithofacies are commonly found above sandstone intervals where pedogenic processes have not modified the strata. Laminations vary between clay and silt-rich layers with some very finegrained sandstone lamina. As a result, lithologies consist of silty-clayey mudstone, claystone, siltstone, sandy siltstone, and very fine-grained sandstone. In the Boswell Pit exploration core, carbonized plant debris is common throughout cored intervals of this lithofacies (Figure 5).

\subsubsection{Mottled ripple-laminated/horizontally bedded sandstone}

This dinosaur track-bearing, sandstone lithofacies consists of moderately well to well-sorted, angular to sub-rounded, medium silt to fine sand (average of very fine sand) grains (Figure 6A, B, and C). At the dinosaur track site, oscillation ripples and Skolithos burrows occur within this track-bearing horizon. (Figures 1 \& 5). Framework grains within this horizon are dominated by quartz (95\%) with lesser amounts of orthoclase feldspar, sedimentary rock fragments (chert), clay minerals, muscovite, and reddish-brown organic matter.

\subsubsection{Ripple cross-laminated sandstone}

The ripple cross-laminated sandstone lithofacies consists of moderately well to well-sorted, angular to subrounded, medium silt to fine sand (with average of very fine sand) grains. Ripple forms vary from symmetrical (oscillation) with approximate wave heights of $0.5-1 \mathrm{~cm}$ and wavelengths of $4 \mathrm{~cm}$, to asymmetrical (current) having wave heights that average about $3.5 \mathrm{~cm}$ and wavelengths ranging between 10 and $15 \mathrm{~cm}$.

\subsubsection{Horizontally-bedded sandstone}

At the dinosaur track and Starr Pit sites, this lithofacies consists of moderately well to well sorted, very angular to angular, medium silt to fine sand (average of fine sand) grains (Figure 6D). Quartz comprises 93\% of the framework grains of this sandstone with lesser 
Table 3. Lower Dakota Formation lithofacies

\begin{tabular}{|c|c|c|}
\hline Lithofacies & Descriptions & Interpretations \\
\hline $\begin{array}{l}\text { Laminated clay and silty mudstone/ } \\
\text { shale }\end{array}$ & $\begin{array}{l}\text { Pyrite-bearing carbonaceous silty mudstone, } \\
\text { clayey mudstone, claystone, siltstone, sandy } \\
\text { siltstone, and very fine-grained sandstone. Car- } \\
\text { bonized plant debris is common throughout the } \\
\text { cored intervals, dinosaur tracksite and Starr Pit } \\
\text { sections. }\end{array}$ & $\begin{array}{l}\text { Estuarine bay fill - tidal mudflat set- } \\
\text { tings. }\end{array}$ \\
\hline $\begin{array}{l}\text { Mottled ripple-laminated/horizon- } \\
\text { tally bedded sandstone }\end{array}$ & $\begin{array}{l}\text { Consists of moderately well to well-sorted, an- } \\
\text { gular to sub-rounded, medium silt to fine sand } \\
\text { (with average of very fine sand) in the form of } \\
\text { oscillation ripples ( } 0.5-1 \mathrm{~cm} \text { height), mottled } \\
\text { by Skolithos trace fossils. }\end{array}$ & $\begin{array}{l}\text { Bay head delta - estuarine tidal flat } \\
\text { setting. }\end{array}$ \\
\hline Ripple cross-laminated sandstone & $\begin{array}{l}\text { Very fine to fine-grained subarkose, having wave } \\
\text { heights that average about } 3.5 \mathrm{~cm} \text { and wave } \\
\text { lengths averaging } 12 \mathrm{~cm} .\end{array}$ & $\begin{array}{l}\text { Lower fluvial valley - bay head } \\
\text { delta setting. }\end{array}$ \\
\hline Horizontally bedded sandstone & $\begin{array}{l}\text { Fine-grained subarkose, consists of moderately } \\
\text { well to well sorted, very angular to angular, } \\
\text { medium silt to fine sand (average of fine sand) } \\
\text { grains (Figure 6D). Framework grains of this } \\
\text { sandstone are dominated by quartz (93\%) with } \\
\text { lesser amounts of sedimentary rock fragments } \\
\text { (chert), feldspar, and clay minerals. }\end{array}$ & $\begin{array}{l}\text { Lower fluvial valley - bay head } \\
\text { delta setting. }\end{array}$ \\
\hline
\end{tabular}

amounts of sedimentary rock fragments (chert), feldspar, and clay minerals. Planar-bedded sandstone and siltstone dominate the upper $97 \mathrm{~cm}$ of the section at the dinosaur track site.

\subsubsection{Tabular cross-bedded sandstone}

Sandstone layers within the Dakota Formation outcropping in Jefferson County, Nebraksa consist of wellsorted, extremely friable, fine-grained subarkoses. Sandstone intervals in the lower portion of the Dakota Formation at the dinosaur track site and Starr Pit are cross-bedded, consisting of rounded and angular quartz grains and are within a fining-upward portion of a stratigraphic interval of coarsening upward cycles (Figure 5) (Young, 2002; Joeckel et al., 2004). Tabular crossbedded sandstone intervals that are exposed in the dinosaur track site and Starr Pit localities, have cross-bedded sets thicknesses that range from 12 to $25 \mathrm{~cm}$. At the dinosaur tracksite, cross-beds are unidirectional with a strong westerly paleoflow component.

\subsection{Stratigraphic relations between sample sites}

The sampled interval of the Dakota Formation at the Starr Pit section is from the top of a $25 \mathrm{~cm}$-thick sandstone bed (Figure 5). This bed overlies a graygreen to light gray mudstone containing silty lenses with millimeter-scale spheroidal iron oxides and is overlain by a dark gray claystone with iron oxide mottling. This interval is interpreted to be from the same stratigraphic horizon as the dinosaur track-bearing sandstone based upon landscape position, stratigraphic sequence of beds, relative position to each other along strike of the fluvial/estuarine depositional pattern of the region, and their unique lithologic similarities (Figures 1 \& 5). The Bosewell Pit exploration core samples, consisting mostly of sphaerosideritebearing mottled clayey mudstone, stratigraphically overlaps the section at the dinosaur track site locality, and may be equivalent to the upper $30 \%$ of the section exposed at Starr Pit, based mostly upon landscape position (Figures 5 \& 6A,B). 

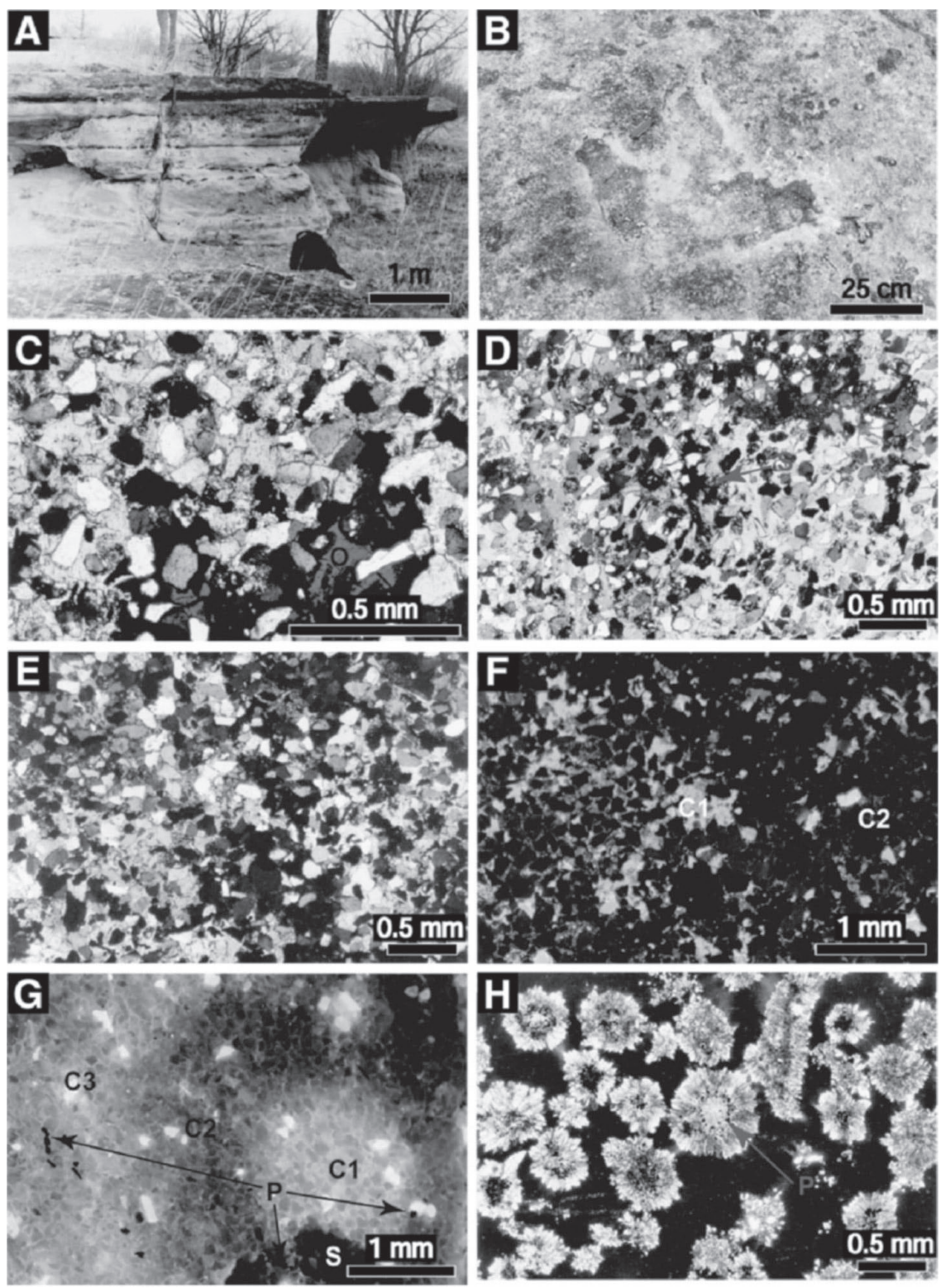

Figure 6. Field photographs of the dinosaur tracksite and photomicrographs exhibiting characteristics of cements sampled as part of this study. A) Outcrop exposure of fluvial bar complex at the dinosaur tracksite. Tracks are on the upper surface. Erosional profile illustrates pervasive cementation at the top of the bed. Hammer for scale. B) Track shows three, broad digits and rounded heel characteristic of many ornithopod dinosaurs. C) Photomicrograph of section of the track-bearing horizon. Note uniform large poikilotopic calcite domain, angularity of grains, and organic matter (O). Photomicrograph taken under crossed polars. D) Thin section photomicrograph of sandstone from the Starr Pit section. Note the three poikilotopic calcite domains and the siderite (S) cement. Photomicrograph taken under crossed polars. E) Crossed polarized photomicrograph of cemented layer $0.5 \mathrm{~m}$ below track-bearing horizon. Note poikilotopic domains of blocky calcite. F) Cathodoluminescent photomicrograph of cemented layer $0.5 \mathrm{~m}$ below track-bearing horizon. Note two distinct luminescent zones (C1 and C2). G) Thin slab cathodoluminescence photomicrograph of cemented horizon from the Starr Pit section. Note three distinct luminescent cement zones (C1, C2, and C3), siderite cement $(\mathrm{S})$, and disseminated pyrite $(\mathrm{P}) . \mathrm{H})$ Photomicrograph under cross polarized conditions of sphaerosiderite nodules picked from the Bosewell pit core of the Yankee Hill Brick and Tile Company. Note the variety of sphaerosiderite shapes (individual radial concentric, cluster, and elongate array). Also note concentration of pyrite $(\mathrm{P})$ cubes throughout the concretions.

The relative lack of sandstone lithofacies and large percentage of blocky mudstone lithofacies, suggest that the Bosewell Pit locality may have formed in an interfluve setting. The dinosaur tracksite and Starr Pit localities contain sandstones, indicating their paleolandscape position proximal to a higher flow regime within a fluvial/estuarine valley (Table 3, Figure 4).

\subsection{Cements and paragenesis}

Blocky, poikilotopic calcite cements are pervasive within studied sandstone intervals from both the dinosaur tracksite and Starr Pit localities (Figure 6C, D, \& E). These calcite cements envelop trace amounts of earlier diagenetic cement phases, including pyrite, siderite, 

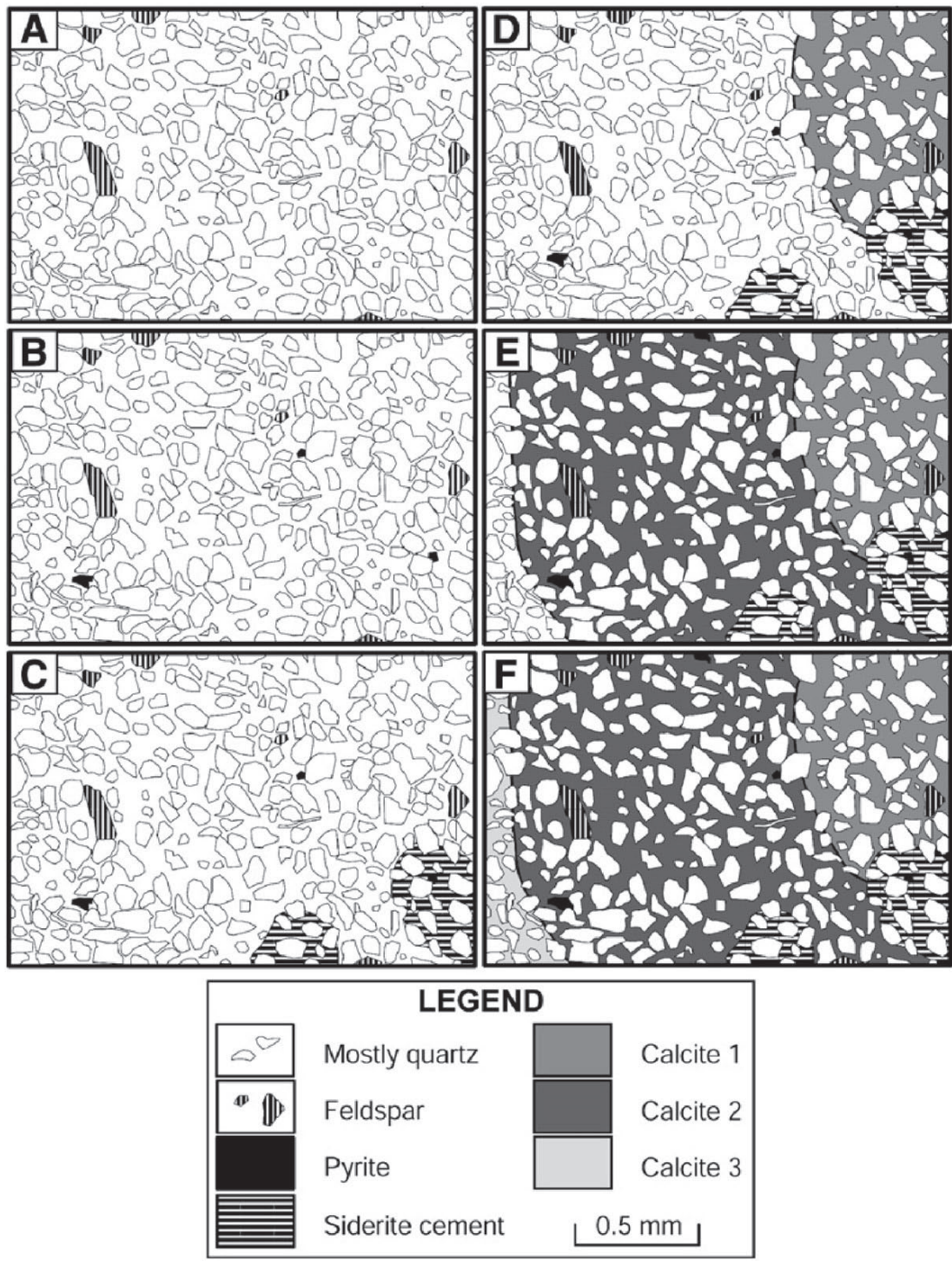

Figure 7. These diagrams exhibit a stepwise progression of cementation of strata sampled from the Starr Pit section. Diagrammed from cathodoluminescense photomicrograph shown in Figure 6G. A) Sketch of the uncemented grains. B) Disseminated pyrite precipitation. C) Sparse siderite precipitation. D) Precipitation of cathodoluminescent cement zone C1, a brightly-luminescent core of blocky poikilotopic calcite. E) Followed by precipitation of a dully-luminescent mantle of calcite, CL cement zone C2. F) A pore-filling brightly-luminescent zone (C3) marks the final phase of early cementation. (Note that later fracture filling calcite (C4) is not diagrammed).

and iron oxides. High minus-cement-porosity $(\sim 47 \%)$ and low grain-to-grain contacts $(\sim 2.5)$ in the sandstone samples studied indicate early lithification prior to loading by overlying strata. Cathodoluminescense (CL) petrography reveals two temporally distinct calcite cement zones within the track-bearing horizon (Figure 6E and F) and four temporally distinct calcite cement zones within coeval strata at Starr Pit (Figure 6G).

\subsubsection{Early calcite cements and minor cement phases}

The dinosaur track-bearing sandstone is cemented with blocky, poikilotopic calcite that comprises approximately $47 \%$ of the whole rock volume. The pervasive calcite cement envelops an iron-rich liesegang-type banding. Poikilotopic domains average $1.7 \mathrm{~mm}$ in diameter. CL petrography reveals a brightly luminescent calcite-cement zone bounded by a later dully-luminescent zone (Figure 6F). Sample minus-cement porosity is approximately $52 \%$, and average grain-to-grain contacts equals 2.3.

The blocky poikilotopic calcite cement in the sandstone interval $0.5 \mathrm{~m}$ below the track-bearing layer comprises approximately $30 \%$ of the whole rock volume. In this interval the cement envelops trace amounts of pyrite and siderite cements. Poikilotopic domains average $2.3 \mathrm{~mm}$ in diameter. Primary and secondary porosity within this interval is approximately $6 \%$. CL petrography reveals a brightly luminescent calcite-cement zone and minor amounts of later calcite-cement zone with 
dull luminescence. The minus-cement porosity of this sample is approximately $41 \%$, and grain-to-grain contacts an average of 2.8 .

Petrographic similarities between the dinosaur tracksite and Starr Pit sandstones include: 1) The Starr Pit sandstone interval, like the dinosaur track-bearing interval, is pervasively cemented by blocky, poikilotopic calcite that comprises approximately $47 \%$ of the whole rock volume. 2) As with the interval $0.5 \mathrm{~m}$ below the track-bearing horizon, the early diagenetic calcite cement envelops trace amounts of earlier pyrite and siderite cements. 3) Poikilotopic domains average $2.1 \mathrm{~mm}$ in diameter. 4) CL petrography reveals a brightly luminescent calcite-cement zone bounded by a later dully luminescent zone (Figure 6G).

In both the dinosaur tracksite and Starr Pit samples the first phase of calcite (C1) cementation included multiple nucleation points where a brightly luminescent zone precipitated. However, a notable difference in the $\mathrm{CL}$ cement zone forms is apparent within samples from these locations. The Starr Pit (SP) C1 cements display a well-defined concentric and spherical form approximately $1 \mathrm{~mm}$ in diameter. These cement spheres are overgrown by a more dully-luminescent concentric calcite zone (SP C2). A brightly luminescent zone of calcite cement (SP C3) later filled all remnant pore spaces (Figure 6 and Figure 7). The dinosaur tracksite (DTS) C1 cements maintain a sub-spherical form, while $\mathrm{C} 2$ cements from both sampled horizons lack regularity of form (Figure 6F).

\subsubsection{Late calcite cement phases}

Sandstones sampled from both the dinosaur tracksite and the Starr Pit sections contain multiple cement phases, as determined by CL petrography. However, late cement phases are identified in the track-bearing horizon and the Starr Pit sandstone as brightly luminescent, fracture-filling calcite cements. The maximum observed fracture width is $0.25 \mathrm{~mm}$ within the dinosaur track-bearing sandstone and $0.65 \mathrm{~mm}$ in the Starr Pit sample. These cement phases are hereafter referred to as DTS C3 and SP C4.

\subsubsection{Sandstone paragenesis}

The paragenetic cement history of the upper horizon at the dinosaur tracksite, from oldest to youngest, includes precipitation of authigenic pyrite, siderite, followed by formation of liesegang-type bands, and precipitation of calcite cements. From the lower interval, the paragenetic history, from oldest to youngest, begins with authigenic pyrite precipitation, minor siderite cementation, calcite cementation followed by partial dissolution of calcite cements.
At Starr Pit, the paragenetic cement history of the sampled interval, from oldest to youngest, begins with pyrite precipitation, followed by siderite cementation, precipitation of blocky poikilotopic calcite cements, and ends with the precipitation of fracture filling calcite (Figure 7).

\subsection{Stable isotope data}

\subsubsection{Dinosaur tracksite}

The early, brightly luminescent calcite cements (DTS C1) from the track-bearing horizon have $\delta^{18} \mathrm{O}$ values ranging between -9.89 and $-6.71 \%$ and a positive covariance with $\delta^{13} \mathrm{C}$ values that range from -28.01 to - 20.34\%o. Later dully luminescent calcite cements (DTS C2) from the same horizon have $\delta^{18} \mathrm{O}$ values that tightly cluster around $-9.42 \%$ o (standard deviation $=0.28$ ), while the $\delta^{13} \mathrm{C}$ values are more variable, ranging between -28.47 and $-21.22 \%$ o (Figure 8 ).

The early brightly luminescent calcite cement phase within the horizon located $0.5 \mathrm{~m}$ below the track-bearing horizon (DTS .5b C1) has $\delta^{18} \mathrm{O}$ values that cluster tightly around $-8.16 \%$ o (standard deviation $=0.31)$ and $\delta^{13} \mathrm{C}$ values ranging between -17.91 and $-13.82 \%$. The later dully luminescent calcite cements (DTS .5b C2) from this horizon have $\delta^{18} \mathrm{O}$ values that tightly cluster around $-8.26 \%$ (standard deviation $=0.19$ ), whereas the $\delta^{13} \mathrm{C}$ values range from -15.34 to $-14.13 \%$ o. Overall, both the dull and bright luminescent cements within this sandstone stratum have stable $\delta^{18} \mathrm{O}$ values clustering around $-8.2 \%$ and $\delta^{13} \mathrm{C}$ values ranging between -17.91 and $-13.82 \%$ (Figure 8).

\subsubsection{Starr Pit section}

Luminescent cement zones from the horizon at the Starr Pit section include an early bright core (SP C1), a later dull mantle (SP C2), a final pore-filling brightly luminescent rim (SP C3), and a brightly luminescent calcite fracture fill (SP C4) (Figure 7). SP C1 has $\delta^{18} \mathrm{O}$ values ranging between -8.18 and $-6.32 \%$ o that positively covaries with $\delta^{13} \mathrm{C}$ values ranging from - 21.71 to $-19.33 \%$. SP C2 has $\delta^{18} \mathrm{O}$ values that tightly cluster around $-3.95 \%$ o (standard deviation $=0.19$ ), while $\delta^{13} \mathrm{C}$ values range from -17.88 to $-13.15 \%$. SP C3 has $\delta^{18} \mathrm{O}$ compositions tightly clustered around $-5.81 \%$ o (standard deviation $=0.25$ ) and more variable $\delta^{13} \mathrm{C}$ values ranging between -28.02 and $-25.67 \%$. SP C 4 has $\delta^{18} \mathrm{O}$ values that are tightly clustered around $-7.74 \%$ (standard deviation $=0.08$ ) and $\delta^{13} \mathrm{C}$ values ranging from -28.03 to $-26.18 \%$ o (Figure 8 ). 


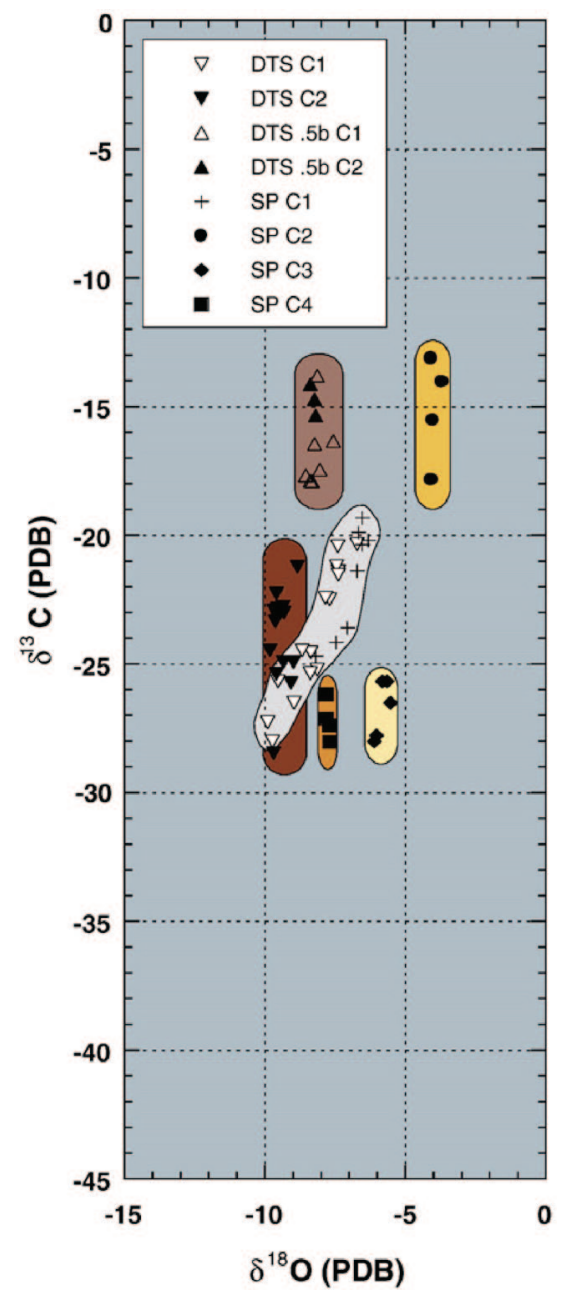

Figure 8. Stable isotopic compositions of early diagenetic calcite cement zones sampled from dinosaur track-bearing horizon and cemented layer $0.5 \mathrm{~m}$ below, and strata equivalent to the track-bearing horizon from the Starr Pit section, Upper Albian (Muddy Cycle), Dakota Formation, Jefferson County, NE. Note covariant trends of DTS and SP C1 zones. Also note relatively invariant $\delta^{18} \mathrm{O}$ values with variable $\delta^{13} \mathrm{C}$ values define multiple MCL's.

\subsubsection{Yankee Hill Brick and Tile, Bosewell Pit section}

The $\delta^{18} \mathrm{O}$ values of sphaerosiderite nodules collected from sample 93-2-6 range from -4.24 to $-3.34 \%$ with an average composition of $-3.62 \%$ (standard deviation $=0.27)$. The $\delta^{13} \mathrm{C}$ values of $93-2-6$ are more variable than $\delta^{18} \mathrm{O}$, ranging between -15.22 and $-12.61 \%$. Sphaerosiderite nodules from 93-2-18 have $\delta^{18} \mathrm{O}$ values ranging between -4.92 and $-4.11 \%$ and have an average composition of $-4.43 \%$ (standard deviation $=0.32$ ). The $\delta^{13} \mathrm{C}$ values of sample $93-2-18$ are, again, more variable than $\delta^{18} \mathrm{O}$, ranging from -16.85 to $-12.77 \%$. The $\delta^{18} \mathrm{O}$ values of sphaerosiderite nodules collected from sample 93-2-22 range from - 4.15 to $-3.91 \%$ o with a mean composition of $-4.00 \%$ o (standard devia-

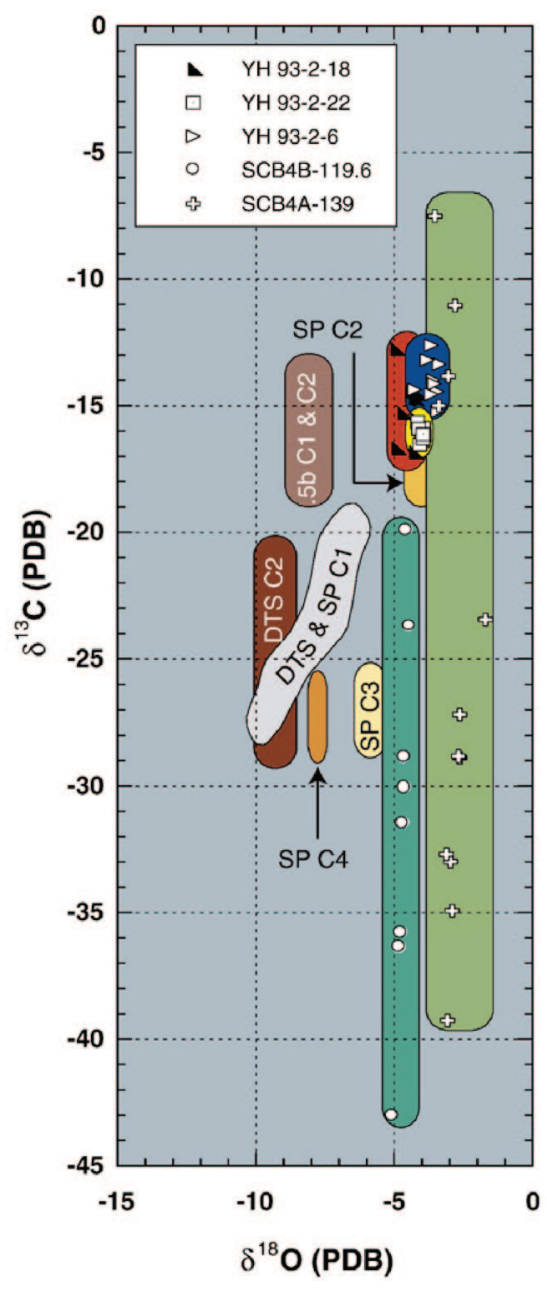

Figure 9. Stable isotopic compositions of paleosol sphaerosiderites from approximately coeval Dakota Formation strata in Lancaster County, Nebraksa and Woodbury County, IA. Sphaerosiderite $\delta^{18} \mathrm{O}$ values are relatively invariant, while $\delta^{13} \mathrm{C}$ values are highly variable, defining MSL's. These data are plotted with data of the calcite cement zones illustrated in Figure 8 .

tion $=0.08)$. As with those determined from the overlying paleosol horizons (Figure 5), the $\delta^{13} \mathrm{C}$ values are more variable than $\delta^{18} \mathrm{O}$, ranging between -16.55 and $-15.66 \%$ o (Figure 9).

\section{Discussion}

\subsection{Sedimentological, petrologic, and geochemical implications}

Dakota Formation sandstone bodies examined from Jefferson County, Nebraska are interpreted to have been deposited as a bar complex in a fluvial-estua- 
rine environment (Brenner et al., 2000). Marine palynomorphs were recovered from interstratified carbonaceous mudstones and shales, indicating this region was periodically inundated by marine waters (Table 2 ). The geographic relationship of the Jefferson County localities is along a northeast-southwest trend, one that is concordant with the depositional geometry of this portion of the Dakota Formation outcrop belt (Witzke and Ludvigson, 1994; Brenner et al., 2000). These relationships coupled with a pre-Dakota Formation topographic study of the region by Joeckel et al. (2005) indicate these localities lay within the same paleo-fluvial/ estuarine valley.

\subsubsection{Lithofacies interpretation}

The following interpretations of characteristic lithofacies in the study area are consistent with recent studies on the stratigraphic relationship of Dakota Formation deposits in southeastern Nebraska and western Iowa by Brenner et al. (2000) and Joeckel et al. (2005). See Hamilton (1994) and Brenner et al. (2000) for regional perspectives on the sequence stratigraphic relationships of the Dakota Formation.

The blocky mudstones are mottled and exhibit characteristics of hydromorphic soils. Therefore, these mudstones were poorly drained and remained saturated and reduced for much of the year (Fanning and Fanning, 1989; Kraus and Aslan, 1993; Stolt et al., 1994; Vepraskas, 1994; McCarthy and Plint, 1999). The presence of pyrite cubes indicates paleogroundwater salinity was at least brackish, if not marine, at an early point within the diagenetic history of these paleosols (Wright, 1986). White et al. (2000) interpreted early pyrite mineralization in the Albian sediments of the Hudson arm of the Cretaceous Western Interior Seaway as an indication of deposition in the central basin of an estuarine system. This interpretation was based on the findings of a study dealing with the interactions of $\mathrm{Fe}$, $\mathrm{C}$, and $\mathrm{S}$ in marine and lacustrine sediments published by Davison (1988) that showed a relationship between marine influence (i.e., brackish water) and the formation of pyrite in uncompacted sediments. Modern sphaerosiderite concretions have been shown to form in reducing wetland soils by Stoops (1983) and Landuydt (1990). Therefore, the sphaerosiderite-bearing blocky mudstones were likely deposited in tidal flat to overbank settings.

Tabular cross-beds near the base of the sandstone body at the dinosaur tracksite show unidirectional paleocurrent directions with a strong westerly component, consistent with an ebb-tide dominated tidal channel positioned on the eastern margin of the Cretaceous Western Interior Seaway (Thomas et al., 1987). Moreover, the oscillation ripples within the track-bearing horizon in conjunction with probable brackish to marine trace fossils (Skolithos) are consistent with deposition within in a tide-dominated estuarine setting (Seilacher, 1967). Tidal laminites with neap-spring cyclicity have been recognized in approximately coeval strata at the Yankee Hill section in nearby Lancaster County, Nebraska (Korus, 2000). Sandstone bodies at the tracksite and Starr Pit localities are overlain by pyrite-bearing, carbonaceous mudstones, consistent with deposition within a marine or brackish setting (Davison, 1988; White et al., 2000). The stratigraphic stacking pattern of central basin estuarine mudstones overlying upper estuary tidally-influenced fluvial sandstones, and the abrupt nature of this transition are indicative of passive drowning by rising sea level. This was followed by a relative decline in base level, as indicated by increasing grain size and local incision of overlying strata on the scale of $0.5 \mathrm{~m}$ (Figure 5). Additionally, sphaerosiderite-bearing mudstones from the Bosewell Pit core are interpreted to be paleosol horizons that formed on interfluves in the same fluvial-estuarine system (Brenner et al., 2000; Joeckel et al., 2005).

Within this region, Dakota Formation sandstone bodies are generally friable. However, sheet-like carbonate-cemented horizons have been noted below lithologic boundaries interpreted as marine flooding surfaces due to their stratigraphic positions at the tops of coarsening upwards fluvial sediments (Taylor et al., 2000). The oxygen isotopic compositions of carbonate cements that precipitated from groundwaters that circulated through these sandstone bodies at the dinosaur tracksite and Starr Pit sections reflect minor changes in source waters from brackish to purely meteoric in composition (Figure 10) (sensu Lohmann, 1988). The earliest physical evidence for changing pore fluid chemistry and, probably, fluid migration within the strata are the disseminated pyrite and siderite phases that are enveloped by blocky, poikilotopic calcite cements. The scarcity of pyrite and siderite indicates that chemical conditions conducive to their precipitation were short lived. Extremely high minus-cement-porosity (> 48\%) within these sandstone bodies, low grain-to-grain contact values $(\sim 2.5)$, the absence of later diagenetic cement phases, and the absence of replacement cement textures indicate that precipitation of phreatic calcite cements must have occurred immediately following the precipitation of pyrite and siderite, preventing significant post-siderite compaction of the strata (Figure 7). Comparison with compaction studies for sandstones (e.g. Baldwin and Butler, 1985; Houseknecht, 1987) indicates cementation occurred within the first $100 \mathrm{~m}$ of burial. Pryor (1973) reported the range of porosity for modern point bar sands to be from 17 to $52 \%$. Therefore, we conclude that carbonate cements stabilized these strata very near the time of deposition. 

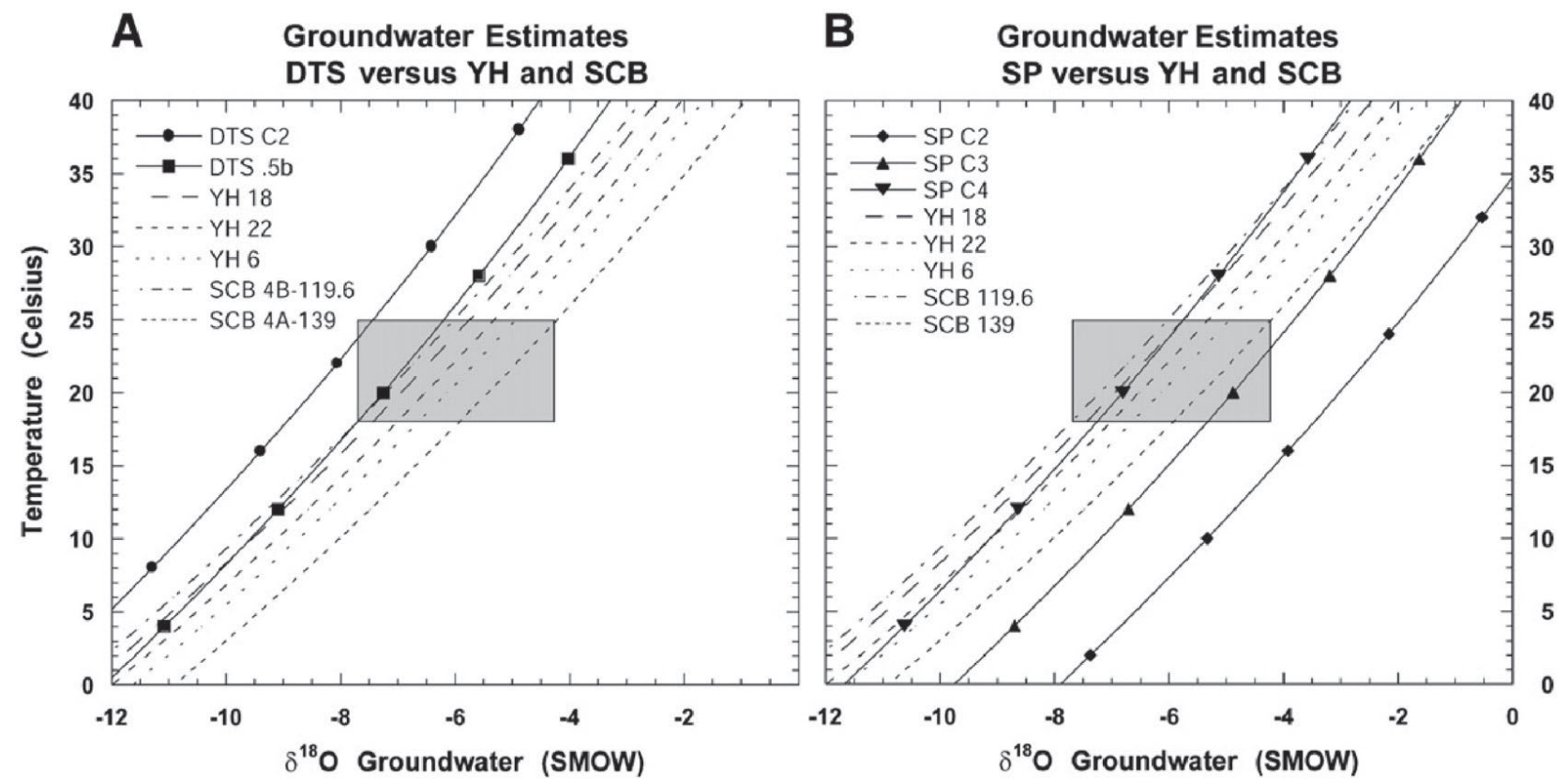

Figure 10. Estimates of groundwater compositions from which calcite and sphaerosiderite cement zones/phases precipitated. Shaded area encompasses minimum and maximum estimates of local paleogroundwater $\delta^{18} \mathrm{O}$ compositions, based on paleosol sphaerosiderite data shown in Figure 9. Temperature ranges of the shaded area are based on mid-Cretaceous leaf physiognomy studies by Wolfe and Upchurch (1987). A) Plot showing calcite cement zones from the dinosaur tracksite section. Note that DTS C2 is more depleted than zone of local paleoaquifer recharge. B) Plot showing calcite cement zone from the Starr Pit section. Note $\mathrm{SP}$ C2 is more enriched than zone of local paleoaquifer recharge.

The positive covariant patterns observed in the carbon and oxygen isotopic compositions of the earliest calcite cements from the dinosaur track-bearing horizon and Starr Pit locales (DTS and SP C1) have distinct trends that converge toward a common heavier carbon and oxygen isotopic composition (Figure 8). These positive covariant trends record either (a) mechanical mixing of two or more cements during sampling, (b) pore fluid evolution resulting from evaporative effects and $\mathrm{CO}_{2}$ degassing or dissolution, or (c) fluid mixing between meteoric and brackish groundwaters at the time of precipitation. Careful mapping of CL cement zones on thin slabs prior to and after microsampling rules out the possibility of mechanical mixing. The blocky poikilotopic fabric of all the CL calcite cement zones is indicative of precipitation within a phreatic groundwater environment where the influences of vadose zone evaporative effects would be either greatly diminished or inconsequential (Tucker, 1981). Therefore, the positive covariant trends $\left(\delta^{18} \mathrm{O}\right.$ and $\left.\delta^{13} \mathrm{C}\right)$ of DTS and SP C1 were most likely produced by the variable mixing of two fluids with distinct end-member compositions.

Fluid mixing could have resulted from periodic flow changes induced by climatic shifts through time, perhaps seasonal to millennial in scale. Fluctuations in relative base level may have been largely driven by climatic shifts. Brenner et al. $(2001,2003)$ presented sedimentological evidence for variable precipitation flux rates on transport of gravel-sized clasts to near base-level within the "Dakota discharge system" of the eastern margin of the Cretaceous Western Interior Seaway. During a period of relatively steady or constant sea level rise, the grain size of sediments accumulating within different portions of the estuary could have been greatly affected by the amount of fluvial discharge and stream competence. Brenner et al. $(2000,2001,2003)$ surmised that coarser-grained sediments were transported farther into the estuary during wetter, high discharge periods and were, conversely, trapped higher in the drainage system during drier, low discharge periods. Furthermore, Brenner et al. (2003) concluded that, within the Nishnabotna Member of the Dakota Formation, transgressive systems tract sediments are represented by sandstones and conglomerates, which are overlain by estuarine or marine mudrocks. Climatic control of sediment transport affects the amount of overall accommodation space within the basin and leads to stratigraphic stacking patterns that are indicative of minor relative sea level fluctuation. This model of sea level control on groundwater systems indicates their compositions likely varied between meteoric and brackish end members.

The temporal relationships of the remaining cement zones (DTS C2, SP C2, C3, and C4) are indeterminate between these two locations. However, their isotopic compositions all define distinct meteoric calcite lines (sensu Lohmann, 1988). Meteoric calcite line trends are 
indicative of diagenetic settings where cements precipitated from meteoric phreatic groundwater environments in which the pore fluid $\delta^{18} \mathrm{O}$ composition and temperature changed very little, while $\delta^{13} \mathrm{C}$ composition of dissolved inorganic carbon varied in response to either progressive rock-water interactions or variable contributions of $\mathrm{CO}_{2}$ from two or more sources (Lohmann, 1988). Meteoric calcite lines of early phreatic cements are useful as paleoclimatic indicators. They are interpreted to result from the precipitation of carbonates in isotopic equilibrium with shallow meteoric groundwaters recording the weighted mean annual $\delta^{18} \mathrm{O}$ of paleoprecipitation at the local mean annual paleotemperature (Hays and Grossman, 1991; Swart et al., 1993).

The meteoric calcite line of SP C2 calcite cement is approximately equal to that from the meteoric sphaerosiderite line (sensu Ludvigson et al., 1998) from roughly coeval paleosols from the Yankee Hill Bosewell Pit drill core in Lancaster County, Nebraksa (Figure 9). However, equivalent meteoric calcite lines and meteoric siderite lines do not signify identical fluid compositions and temperatures, since the ${ }^{18} \mathrm{O}$ fractionation of calcite and siderite differ. Meteoric siderite lines, like meteoric calcite lines, record oxygen isotopic compositions of meteoric phreatic groundwaters from which the paleosol sphaerosiderites precipitated. At several locations along the margins of the Cretaceous Western Interior Seaway, it has been shown that meteoric siderite lines provide a proxy for $\delta^{18} \mathrm{O}$ of local paleoprecipitation (Ludvigson et al., 1996, 1998). The dinosaur tracksite in southeastern Nebraska was formed in a similar setting along the Cretaceous Western Interior Seaway, and is analogous to the sites analyzed by Ludvigson et al. (1998). Therefore, we interpret the meteoric calcite line defined by CL cement phase SP C2 as indicating precipitation from a groundwater system that was dominated by locally recharged water. Remaining Starr Pit calcite cement zones have $\delta^{18} \mathrm{O}$ values that are much more depleted $(\sim 5 \%)$ and were likely precipitated from groundwaters that incorporated recharge from a greater area.

Blocky poikilotopic cements within the Starr Pit sample have little or no relationship with observed CL zone boundaries. Additionally, CL phase boundaries are diffuse in nature, grading from one zone to the next over a distance of approximately $0.01 \mathrm{~mm}$. There is no evidence for dissolution or movement from phreatic to vadose zone along CL boundaries. These characteristics in conjunction with meteoric calcite lines from these horizons indicate that there may have been periods of stasis between cement precipitation; yet, precipitation resumed growth within the same lattice orientation.

\subsection{Estimates of paleogroundwater compositions}

Published ${ }^{18} \mathrm{O}$ fractionation relations for calcite (Friedman and O'Neil, 1977) and siderite (Carothers et al., 1988) have been used to calculate the ranges of fluid $\delta^{18} \mathrm{O}$ values and temperatures that satisfy oxygen isotopic equilibrium for the studied calcite and siderite cements. Estimates of the paleogroundwater $\delta^{18} \mathrm{O}$ compositions from which the calcite cements precipitated are shown in Figure 10. Isotopic compositions of groundwater were constrained by temperature estimates, based on the analyses of leaf physiognomy, that indicate mid-Cretaceous mean annual temperatures at a paleolatitude of $34^{\circ} \mathrm{N}$ were approximately $21^{\circ} \mathrm{C}$, with a range between $18{ }^{\circ} \mathrm{C}$ and $25^{\circ} \mathrm{C}$ (Wolfe and Upchurch, 1987; Spicer and Corfield, 1992). This temperature range is also within the envelope of estimates used by Barron (1983) to constrain a four-times present atmospheric $\mathrm{CO}_{2}$ simulation of the Cretaceous climate system.

The estimated $\delta^{18} \mathrm{O}$ compositions of paleogroundwater from which the early diagenetic carbonate cements precipitated allow for comparison of individual groundwater systems. Since sphaerosiderites formed in interfluvial, coastal wetland soils, most of the groundwater recharge within these soils was locally derived. Given normal (e.g. evaporative effects are minimized) recharge of sandy paleo-aquifers through seepage and stream loss on the "drainage basin scale," sphaerosiderite $\delta^{18} \mathrm{O}$ compositions should be more enriched, with respect to ${ }^{18} \mathrm{O}$, than all measured early diagenetic carbonate cement compositions derived from the greater drainage basin area. A greater catchment area for groundwater seepage recharge allows for continental effects (sensu Rozanski et al., 1993) to modify (i.e. deplete) $\delta^{18} \mathrm{O}$ values of precipitation. Additional recharge of the paleogroundwater system is achieved through stream loss. Rivers have the potential to drain very large regions and their waters typically have very depleted $\delta^{18} \mathrm{O}$ values compared to that of locally derived meteoric groundwater (e.g. Dettman and Lohmann, 2000) (Figure 11).

The $\delta^{18} \mathrm{O}$ values of groundwaters from sampled carbonate cements are estimated to range between -8.9 and $-1.9 \%$ SMOW (Standard Mean Ocean Water). Paleogroundwater estimates for meteoric sphaerosiderite lines from the Yankee Hill Bosewell Pit paleosols range from -7.4 to $-4.9 \%$ sMOW (Figure 10). Ludvigson et al. (1998) reported meteoric sphaerosiderite line values of two sphaerosiderite-bearing paleosol horizons from northwestern Iowa (Sioux City Brick Company, Sergeant Bluff, Iowa; Witzke and Ludvigson, 1994) as having $\delta^{18} \mathrm{O}$ compositions equal to $-4.7 \%$ o $\pm 0.2 \%$ and $-2.9 \%$ o $\pm .5 \%$ PDB (Figure 9). Paleogroundwater esti- 


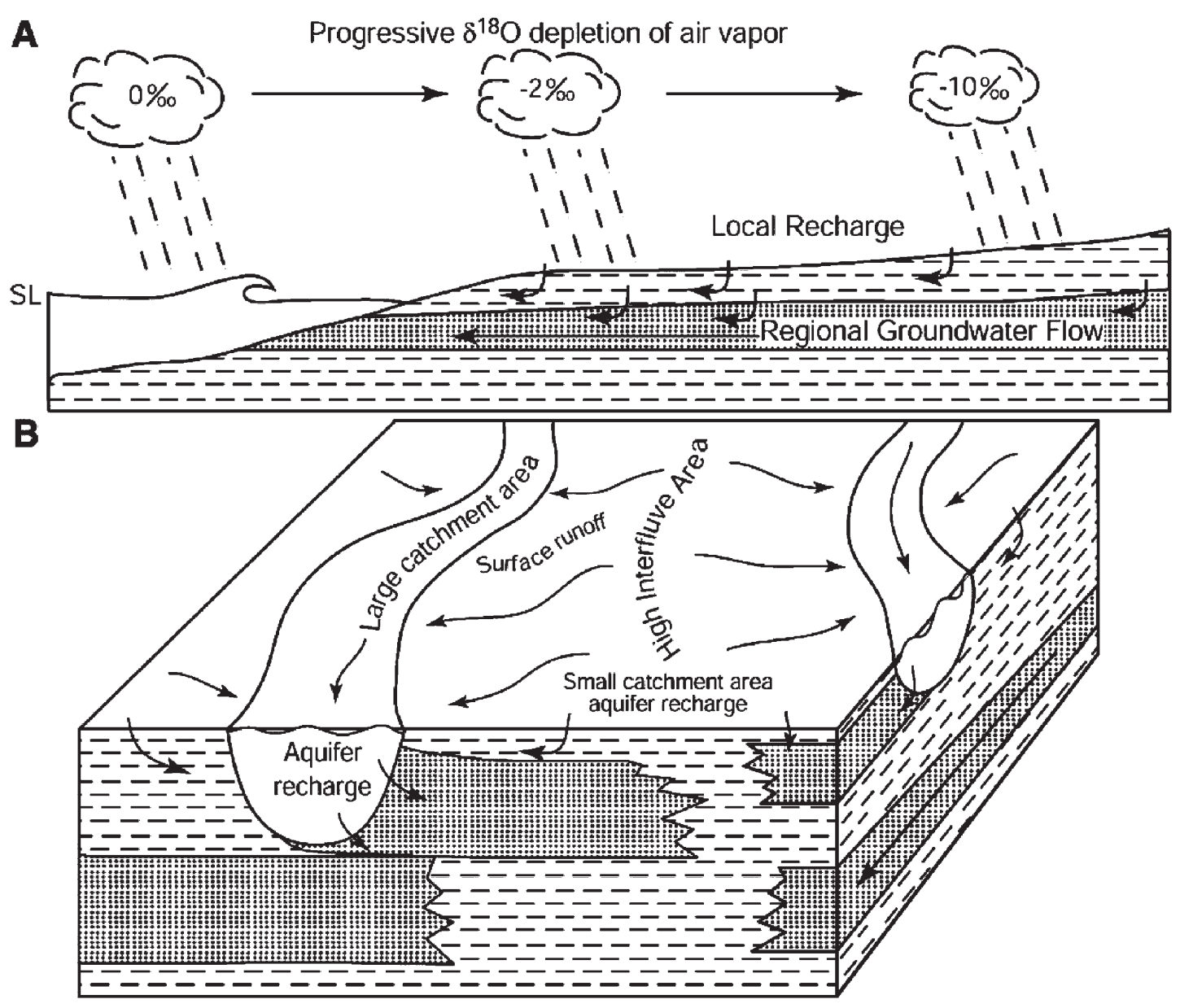

Figure 11. Diagrammatic sketches illustrating the concept of locally versus regionally recharged groundwater. A) Shows the progressive inland depletion, due to continental effect (Rozanski et al., 1993), of $\delta^{18} \mathrm{O}$ composition of a vapor mass as it travels from sea to some point on land. Not to scale, $\delta^{18} \mathrm{O}$ values are hypothetical. SL = sea level. B) Box diagram illustrates recharge of different landscape positions in a drainage system. High interfluve areas (analogous with paleosol environments, commonly finer grained) are primarily recharged by local precipitation. Laterally accreting fluvial deposits (analogous with bar sand deposits, typically coarser grained) are recharged by waters derived from surface runoff, infiltration of surface water, and seepage from rivers and streams draining a large catchment area. Groundwaters derived from larger catchment areas are more depleted with respect to ${ }^{18} \mathrm{O}$ than locally recharged groundwater.

mates for Sioux City Brick Company meteoric sphaerosiderite lines range from -7.7 to $-4.2 \%$ SMOW (Figure 10). The exact timing of sphaerosiderite precipitation between two paleosol horizons, much less two locations, cannot be determined. Therefore, paleogroundwater estimates based on Yankee Hill Bosewell Pit and Sioux City Brick Company meteoric sphaerosiderite lines are interpreted to represent a range of groundwater $\delta^{18} \mathrm{O}$ compositions derived from local paleoprecipitation. The $\delta^{18} \mathrm{O}$ composition of groundwaters that produced DTS C2 and DTS .5b C1 and C2 range from -8.9 to $-6.2 \%$ SMOW (Figure 10A). These values are on average more depleted than those calculated from Yankee Hill Bosewell Pit and Sioux City Brick Company meteoric sphaerosiderite lines and are indicative of groundwaters that were recharged by regionally derived sources.

Paleogroundwater estimates for Starr Pit C2 and C3 meteoric calcite lines range from -3.4 to $-1.9 \%$ o and -5.3 to $-3.8 \%$ SMOW, respectively (Figure 10B). While SP C3 estimates are within the range of those calculated from roughly coeval meteoric sphaerosiderite lines from Bosewell Pit and Sioux City Brick Company, SP C2 are more enriched with respect to ${ }^{18} \mathrm{O}$. We interpret this to be a function of one or more of the following: a) evaporation of source water prior to aquifer infiltration, b) local paleoprecipitation was less evolved, e.g. continental effects on $\delta^{18} \mathrm{O}$ of precipitation (Dansgaard, 1964), than in the upstream reaches, c) aquifer source water was less depleted by rain-out effect (sensu Dans- 
gaard, 1964), and/or d) meteoric sphaerosiderite lines from the Bosewell Pit and Sioux City Brick Company do not adequately measure the full $\delta^{18} \mathrm{O}$ variability of local paleoprecipitation. Local variability in $\delta^{18} \mathrm{O}$ composition of rainfall can be on the order of several per mil (e.g. rainout effect, sensu Rozanski et al., 1993) during a single rain event. Precipitation has also been shown to have a strong seasonal variability of $\delta^{18} \mathrm{O}$ compositions, such that winter values are generally more depleted than summer values. Water derived from isotopically "skewed" rainfall events can dominate recharge of local aquifer systems and those temporarily separated from regional recharge. Thus, $\delta^{18} \mathrm{O}$ values measured from calcite cement zone C2 from the Starr Pit section may extend the range of values consistent with local paleoprecipitation.

Groundwater estimates from fracture-filling calcite cements (SP C4) have $\delta^{18} \mathrm{O}$ compositions between -7.3 and $-5.7 \%$ SMOW. These values are consistent with those of the Bosewell Pit and Sioux City Brick Company sphaerosiderites. However, the timing of cementation is poorly constrained and the similarities in groundwater $\delta^{18} \mathrm{O}$ compositions may be fortuitous.

Several statistical regression analyses have been published that correlate mid-Cretaceous paleosol sphaerosiderite oxygen isotopic compositions with latitude and paleotemperature (White et al., 2001; Ufnar et al., 2002). Each of these regressions allows for the calculation of $\delta^{18} \mathrm{O}$ composition of local paleoprecipitation. A latitude-based linear regression published by White et al. (2001) yields a $\delta^{18} \mathrm{O}$ value of $-8.1 \%$ o SMOW at $34^{\circ} \mathrm{N}$ paleolatitude. Similarly, a polynomial regression published by Ufnar et al. (2002) yields a $\delta^{18} \mathrm{O}$ value of $-6.6 \%$ sMOW for the same paleolatitude. Finally, a temperature-based linear regression published by White et al. (2001) yields a $\delta^{18} \mathrm{O}$ value of $-6.7 \%$ SMOW for a paleotemperature of $21^{\circ} \mathrm{C}$. With the exception of White et al.'s (2001) latitude-based equation, calculated paleoprecipitation $\delta^{18} \mathrm{O}$ compositions are within the range of locally recharged paleogroundwater estimates ( -7.7 to $-4.2 \%$ sMOW). Each of the subsequent calculations are in direct agreement with mean estimates $(-6.2 \%$ sMOW) of groundwater $\delta^{18} \mathrm{O}$ compositions from the Bosewell Pit and Sioux City Brick Company samples.

\subsection{Implications for track preservation}

Preferential cementation of capping sandstone bodies within aggradational nonmarine deposits has been shown to occur below marine flooding surfaces (Taylor et al., 2000). Lockley et al. (1992) and Lockley and Hunt (1995) proposed the preservation of track-bearing horizons may be in response to relative increases in sea level. In this paper, we have provided sedimentological evidence that places the dinosaur track bed of Jefferson County, Nebraska at a depositional transition stratigraphically above fluvially-dominated bayhead sandstone, and immediately below estuarine bay mudstone. The presence of marine palynomorphs in interbedded mudstones further supports our interpretation of estuarine conditions in this region. Palynomorphs place these deposits within the Upper Albian Muddy Cycle, which can be traced across the Cretaceous Western Interior Seaway. Young (2002) identified eight parasequences within the Muddy Cycle deposits of the Dakota Formation along the eastern margin of the Cretaceous Western Interior Seaway. Though limited exposures and biostratigraphic controls in the area do not allow for determination of which parasequence is represented in this study, we can unambiguously state that the top of the track-bearing sandstone is the boundary between two parasequences, based on stratigraphic position between upward-coarsening fluvially-dominated deposits and finer-grained sediments with marine affinities.

Early diagenetic calcite cementation of sandstones of the Dakota Formation in Jefferson County, Nebraska played a major role in the preservation of the easternmost dinosaur tracks known from this region. Evaluation of stable isotope cement geochemistry revealed that mixing of a meteoric-dominated groundwater system with one that was largely brackish to marine marked the inception of calcite cementation. Later diagenetic cement phases originated from purely meteoric groundwater systems. Evaluation of carbon and oxygen isotopic compositions of these early diagenetic carbonate cements enabled us to establish the environment of precipitation, determine the paleogroundwater $\delta^{18} \mathrm{O}$ compositions, and reconstruct the post-depositional history of these strata. Additional sphaerosiderite $\delta^{18} \mathrm{O}$ values measured from nearby, approximately coeval paleosols allowed for comparison of locally recharged groundwater systems.

Moore (1999) introduced the concept of a "subterranean estuary", which involves coastal region aquifers that extend from land to some point offshore, where mixing of seawater with meteoric water takes place below the sediment-water interface. The mixing trend measured from cement zone $\mathrm{C} 1$ from the dinosaur tracksite and Starr Pit sections is interpreted to have precipitated from groundwaters within a "subterranean estuary" system. Precipitation of carbonate cements within Dakota Formation sandstones in Jefferson County, Nebraska was controlled by a relative rise of sea level that placed these estuarine deposits within the phreatic subterranean estuary. As sediments were deposited within the Dakota Formation estuary system of the eastern margin of the Cretaceous Western Interior 

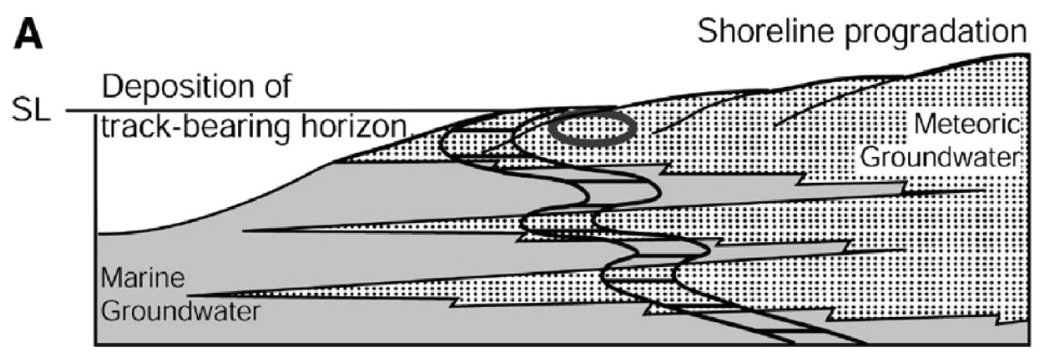

B

Shoreline retrogradation
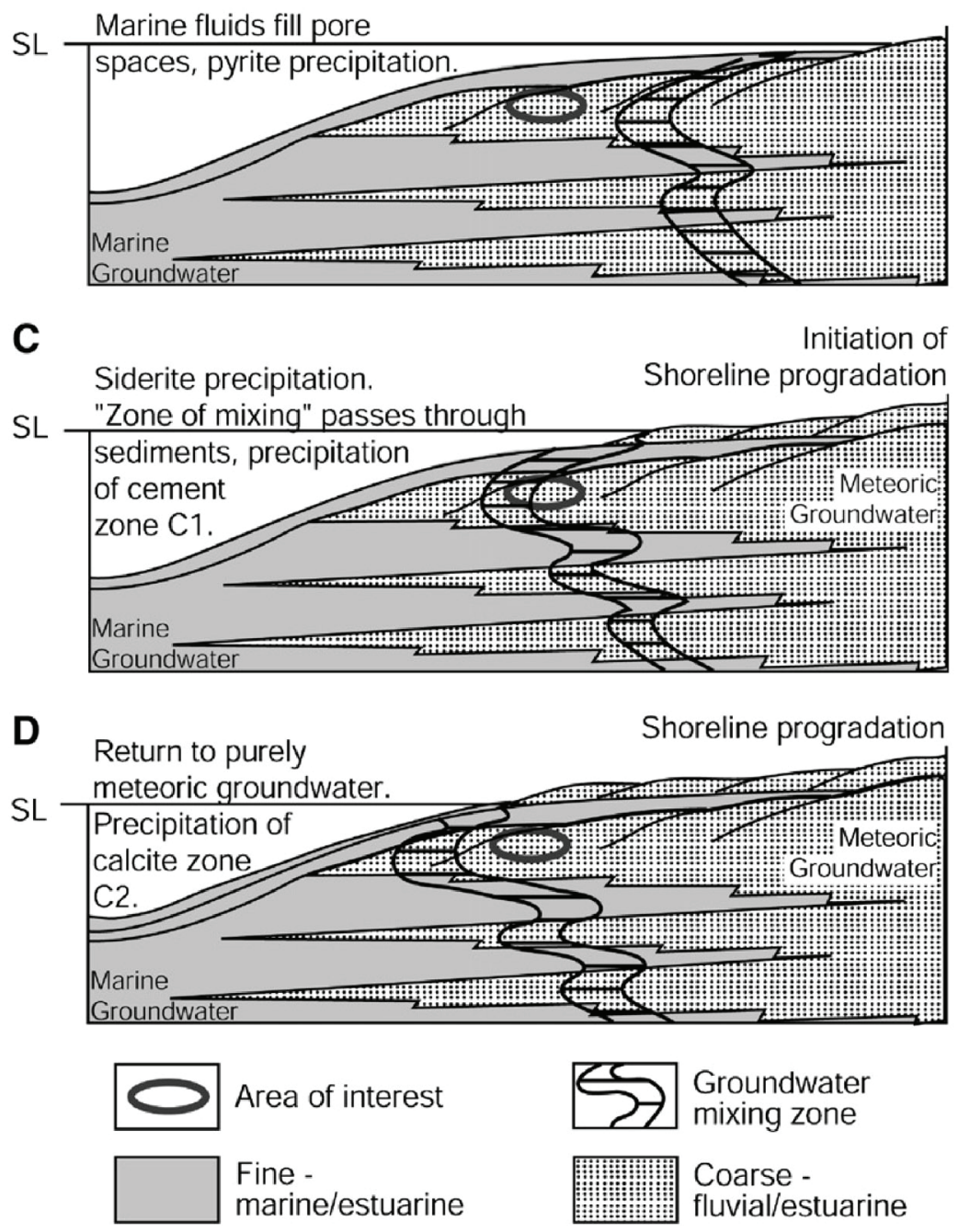

Figure 12. Schematic representation of the effects of relative sea level changes on coastal groundwater systems. A) Sediments deposited at or near local base level in a fluvial/estuarine environment. Groundwater is dominated by fresh to brackish water. Mixing zone of marine with meteoric groundwater is near area of interest. B) Relative sea level rise produces accommodation space for deposition of estuarine bay mud. Groundwater is dominated by marine water. Mixing zone is well inland of the area of interest. Conditions are conducive for pyrite precipitation. C) Reduction of accommodation space and increased sediment discharge has initiated shoreline progradation. Zone of mixing passes through the area of interest. Precipitation of cement zone C1 ensues. D) Progradation of shoreline moves the zone of mixing basinward. Area of interest is dominated by meteoric groundwater. Conditions are conducive for the precipitation of calcite cements with meteoric $\delta^{18} \mathrm{O}$ compositions.

Seaway, accommodation space was reduced and shoreline progradation ensued. Dakota Formation sandstone paleoaquifers were lithified by cements that precipitated from locally-and regionally-recharged meteoric groundwaters as progradation shifted the subterranean estuary basinward (Figures $11 \& 12$ ). 
We propose that the preservation of many coastal track beds is largely controlled by their stratigraphic placement under marine flooding surfaces and that the inception of cementation resulted from changes in groundwater flow in response to a relative sea level rise, and that cementation continued through the depositional cycle. The results of this study concur with the Taylor et al. (2000) study on the sequence stratigraphic controls of carbonate cementation. As well, this study provides a new line of evidence supporting the association of track-bearing intervals within aggradational deposits, as observed by Lockley et al. (1992). We do not imply that the preservation of all track beds is controlled by relative sea level rises. Rather, we encourage the testing of our proposal during further studies of the depositional and diagenetic histories of coastal track beds.

\section{Conclusions}

A dinosaur track-bearing sandstone and several paleosol horizons within the Upper Albian Dakota Formation of the eastern margin of the Cretaceous Western Interior Seaway (Nebraska-Iowa region) have been analyzed. Depositional, stratigraphic, petrologic, and geochemical $\left(\delta^{18} \mathrm{O}\right.$ and $\left.\delta^{13} \mathrm{C}\right)$ examinations of these strata indicate that:

1. Dakota Formation strata in the study area were deposited within fluvial to estuarine environments. The sand-dominated strata were deposited as a bar complex in a fluvial-estuarine setting, while the mud-dominated strata were deposited within the central estuarine bay. Paleosol development was limited to interfluve reaches of the estuarine system. The track-bearing horizon marks a transition between these depositional settings and marks a marine flooding surface within the Muddy Cycle of the Cretaceous Western Interior Basin.

2. Petrographic examination of Dakota Formation sandstone revealed pervasive calcite cementation of the track-bearing horizon. In this area, cemented sandstone strata are rare, except at boundaries interpreted as marine flooding surfaces. The blocky poikilotopic nature of the cements strongly indicates precipitation within the phreatic zone of groundwater. Cathodoluminescence petrography revealed two temporally distinct calcite zones within the track-bearing horizon. Four calcite cement zones were identified from equivalent strata within the Starr Pit sand quarry. Cements within sampled strata from the dinosaur tracksite and Starr Pit sections in Jefferson County, Nebraska are time-rich records of early diagenetic fluid evolution.
3. Oxygen and carbon isotopic compositions of calcite cements from these localities record the geochemical evolution of groundwaters from which these multiple cement zones precipitated. The earliest calcite cement zones at both localities exhibit positive covariant $\left(\delta^{18} \mathrm{O}\right.$ and $\left.\delta^{13} \mathrm{C}\right)$ trends that are geochemically indistinguishable from each other. These cements are interpreted to be coeval and to have precipitated within the same groundwater system. This groundwater system was a mixing zone between meteoric and modified marine and/or brackish pore fluid systems. This phase of cementation was initiated by changing groundwater conditions induced by a relative sea level rise.

4. Other calcite cement zones sampled from sandstones collected from the Jefferson County localities exhibit independent $\delta^{18} \mathrm{O}$ and $\delta^{13} \mathrm{C}$ trends that define unique meteoric calcite lines. Isotopic $\left(\delta^{18} \mathrm{O}\right.$ and $\left.\delta^{13} \mathrm{C}\right)$ data collected from roughly coeval paleosols from nearby Lancaster County, Nebraska and Woodbury County, Iowa exhibit trends that define meteoric sphaerosiderite lines. Both the meteoric calcite lines and meteoric sphaerosiderite lines are interpreted to be the result of precipitation of carbonate cements in isotopic equilibrium with meteoric groundwaters. Yankee Hill Bosewell Pit and Sioux City Brick Company meteoric sphaerosiderite lines serve as proxies for groundwaters that were dominantly derived from local paleoprecipitation. Paleogroundwater $\delta^{18} \mathrm{O}$ estimates for the meteoric sphaerosiderite lines from paleosols of the Muddy Cycle of the region range from -7.4 to $-4.2 \%$ o SMOW. Measured meteoric calcite lines from the DTS are generally more depleted than meteoric sphaerosiderite lines, indicative of groundwater systems that were recharged by regionally extensive flow systems that extended far inland from the coast. The meteoric calcite line of cement zone C2 measured from the Starr Pit is slightly enriched with respect to meteoric sphaerosiderite lines, probably extending the range of local paleoprecipitation $\delta^{18} \mathrm{O}$ composition. To the best of our knowledge, this is the first work to use carbonate cement geochemistry to define locally and regionally derived groundwater systems for a specific study area. Recognition of different geographical extents of paleoaquifer recharge is crucial in developing paleoclimatic and paleoenvironmental interpretations of terrestrial deposits.

5. This study supports the idea that the position of dinosaur track-bearing beds may be at or near sequence boundaries. It is proposed from this study, that the preservation of many coastal track beds may be considerably enhanced, if not largely controlled, by their stratigraphic placement under marine flood- 
ing surfaces. Additionally, the inception of cementation results from changes in groundwater flow in response to a relative sea level rise and that cementation continues through the depositional cycle. The Nebraska tracksite may be unique in that it has not suffered dissolution of early diagenetic carbonate cements. Certainly, there are many sites where original cements remain intact. We encourage further studies of the depositional and diagenetic histories of coastal track beds and hard-cemented sandstone horizons.

Acknowledgments - This project was supported in part by NSF Grant \#EAR 96-28128, G.S.A. Student Research Grant \#6517-99 and a seed grant from the University of Iowa Center for Global and Regional Environmental Research. This work culminates a portion of P. L. Phillips' Ph.D. dissertation research, which was supported in part by a Department of Education GAANN fellowship. We wish to thank the owners of the dinosaur tracksite, the Starr family, operators of the Yankee Hill Brick and Tile properties, and the Sioux City Brick Company for graciously allowing access to exposed sections on their properties and donation of samples from exploration drillcores. D. F. Ufnar, M. G. Lockley, F. Therrien, and F. Surlyk provided critical reviews of this manuscript that proved very helpful. Thanks to Drs. S. J. Carpenter, T. S. White, P. H. Heckel, and K. C Lohmann for discussions and technical assistance. Finally, thanks to K. Saville, L. Wingate, and P.B.C. for assistance with sample preparation and data acquisition.

\section{References}

Baldwin and Butler, $1985 \backsim$ D. Baldwin and C. O. Butler, Compaction Curves, AAPG Bull. 69 (1985), pp. 622-626.

Barron, 1983 E. J. Barron, Warm, equable Cretaceous: The nature of the problem, Earth Sci. Rev. 19 (1983), pp. 305-338.

Brenner et al., $2000<$ R. L. Brenner, G. A. Ludvigson, B. J. Witzke, A. N. Sawistoski, E. P. Kvale, R. L. Ravn, and R. M. Joeckel, Late Albian Kiowa-Skull Creek marine transgression, Lower Dakota Formation, eastern margin of Western Interior Seaway, USA, J. Sediment. Res. 70 (2000), pp. 868-878.

Brenner et al., 20014 R. L. Brenner, G. A. Ludvigson, B. J. Witzke, P. L. Phillips, T. S. White, D. F. Ufnar, and R. M. Joeckel, Aggradation of fluvial gravels during the Late Albian (Lower Cretaceous) Kiowa-Skull Creek marine cycle: Nishnabotna Member, Dakota Formation, cratonic margin of the Western Interior Foreland Basin. In: J. A. Mason, R. F. Diffendal Jr., and R. M. Joeckel, eds., Programs with Abstracts, Seventh International Conference on Fluvial Sedimentology, Open-File Report vol. 60, Conservation and Survey Division, The University of Nebraska-Lincoln (2001), p. 66.

Brenner et al., $2003<$ R. L. Brenner, G. A. Ludvigson, B. J. Witzke, P. L. Phillips, T. S. White, D. F. Ufnar, L. A. Gonzalez, R. M. Joeckel, A. Goettemoeller, and B. J. Shirk, Aggradation of gravels in tidally-influenced fluvial systems, Late
Albian (Lower Cretaceous): Cratonic margin of the North American Western Interior Foreland Basin, Cretac. Res. 24 (2003), pp. 439-448.

Carothers et al., $1988<$ W. W. Carothers, L. H. Adami and R. J. Rosenbauer, Experimental oxygen isotope relation between siderite-water and phosphoric acid liberated $\mathrm{CO}_{2}-$ siderite, Geochim. Cosmochim. Acta 52 (1988), pp. 2445-2450.

Dansgaard, 19644 W. Dansgaard, Stable isotopes in precipitation, Tellus 16 (1964), pp. 436-468.

Davison, $1988<$ W. Davison, Interactions of iron, carbon and sulphur in marine and lacustrine sediments. In: A. J. Fleet, K. R. Kelts, and M. R. Talbot, eds., Lacustrine Petroleum Source Rocks, Special Publication vol. 40, Geological Society (London) (1988), pp. 131-137.

Dettman and Lohmann, 20004 D. L. Dettman and K. C. Lohmann, Oxygen isotope evidence for high-altitude snow in the Laramide Rocky Mountains of North America during the Late Cretaceous and Paleogene, Geology 28 (2000), pp. 243-246.

Fanning and Fanning, $1989<$ D. S. Fanning and M. C. B. Fanning, Soil: Morphology, Genesis, and Classification, John Wiley and Sons, New York (1989).

Folk, $1968 \varangle$ R. L. Folk, Petrology of Sedimentary Rocks, Hemphill's Book Store, Austin, Texas (1968).

Friedman and $\mathrm{O}^{\prime}$ Neil, 1977 I. Friedman and J. R. O'Neil, Compilation of stable isotope fractionation factors of geochemical interest, Professional Paper vol. 440-KK, United States Geological Survey (1977), pp. KK1-KK12.

Gatesy et al., 1999 S. M. Gatesy, K. M. Middleton, F. A. Jenkins Jr. and N. H. Shubin, Three-dimensional preservation of foot movements in Triassic theropod dinosaurs, Nature 399 (1999), pp. 141-144.

Gillette and Lockley, $1989<$ D. D. Gillette and M. G. Lockley, Dinosaur Tracks and Traces, Cambridge University Press, New York (1989).

Hamilton, $1994<$ V. Hamilton, Sequence stratigraphy of Cretaceous Albian and Cenomanian strata in Kansas. In: G. W. Shurr, G. A. Ludvigson and R. H. Hammond, eds., Perspectives on the Eastern Margin of the Cretaceous Western Interior Basin KWIS, Geol. Soc. Am. Spec. Pap. vol. 287 (1994), pp. 79-96.

Hays and Grossman, 1991 P. D. Hays and E. L. Grossman, Oxygen isotopes in meteoric calcite cements as indicators of continental paleoclimate, Geology 19 (1991), pp. 441-444.

Houseknecht, 1987 D. W. Houseknecht, Assessing the relative importance of compaction processes and cementation to reduction of porosity in sandstones, AAPG Bull. 71 (1987), pp. 633-642.

Jenkins et al., $1994 \backslash$ F. A. Jenkins Jr., N. H. Shubin, W. W. Amaral, S. M. Gatesy, C. R. Schaff, L. B. Clemmensen, W. R. Downs, A. R. Davidson, N. Bonde, and F. Osbæck, Late Triassic continental vertebrates and depositional environments of the Fleming Fjord Formation, Jameson Land, East Greenland, Medd. Gronl., Geosci. 32 (1994), pp. 3-25.

Joeckel et al., $2004 \varangle$ R. M. Joeckel, J. Cunningham, R. G. Corner, G. W. Brown, P. L. Phillips, and G. A. Ludvigson, Late Albian dinosaur tracks from the cratonic (eastern) margin of the Western Interior Seaway, Nebraska, USA, Ichnos 11 (2004), pp. 275-384.

Joeckel et al., $2005 \varangle$ R. M. Joeckel, G. A. Ludvigson, B. J. Witzke, E. P. Kvale, P. L. Phillips, R. L. Brenner, S. G. Thomas, 
and L. M. Howard, Palaeogeography and fluvial to estuarine architecture of the Dakota Formation (Cretaceous, Albian), Eastern Nebraska, USA. In: M. D. Blum, S. B. Marriott and S. Leclair, eds., Fluvial Sedimentology VII, International Association of Sedimentologists Special Publication vol. 35 (2005), pp. 453-480.

Korus, 20004 J. T. Korus, Estuarine deposition and tidal rhythmites of the Dakota Formation (upper Albian), southeastern Nebraska, Program and Proceedings of the Nebraska Academy of Sciences vol. 110 (2000), p. 67.

Kraus and Aslan, 19934 M. J. Kraus and A. Aslan, Eocene hydromorphic paleosols: Significance for interpreting ancient floodplain processes, J. Sediment. Petrol. 63 (1993), pp. 453-463.

Kurtz et al., 2001 W. J. Kurtz, M. G. Lockley, and D. J. Engard, Dinosaur tracks in the Plainview Formation, Dakota Group (Cretaceous, Albian) near Cañon City, Colorado: A preliminary report on another "Dinosaur Ridge", Mt. Geol. 38 (2001), pp. 155-164.

Kvale et al., 2001 E. P. Kvale, G. D. Johnson, D. L. Mickelson, K. Keller, L. C. Furer, and A. W. Archer, Middle Jurassic (Bajocian and Bathonian) dinosaur megatracksites, Bighorn Basin, Wyoming, USA, Palaios 16 (2001), pp. 233-254.

Landuydt, $1990<\mathrm{C}$. J. Landuydt, Micromorphology of iron minerals from bog ores of the Belgium Campine area. In: L. A. Douglas, Editor, Developments in Soil Science 19: Soil Micromorphology: A basic and Applied Science, Elsevier, Amsterdam (1990), pp. 289-294.

Lockley, 1988 M. G. Lockley, Dinosaurs near Denver. In: G. S. Holden, Editor, Geol. Soc. Am. Fieldtrip Guidebook 1988: Professional Contributions - Colorado School of Mines, vol. 12 (1988), pp. 288-299.

Lockley, $1989 \varangle$ M. G. Lockley, Summary and prospectus. In: D. D. Gillette and M. G. Lockley, eds., Dinosaur Tracks and Traces, Cambridge University Press, New York (1989), pp. 441-447.

Lockley, 1991 M. G. Lockley, Tracking Dinosaurs: A New Look at an Ancient World, Cambridge University Press, New York (1991).

Lockley and Hunt, $1995<$ M. Lockley and A. P. Hunt, Dinosaur Tracks and Other Fossil Footprints of the Western United States, Columbia University Press, New York (1995).

Lockley and Peterson, $20024 \mathrm{M}$. Lockley and J. Peterson, A Guide to the Fossil Footprints of the World, Lockley-Peterson Publication, Denver, Colorado (2002).

Lockley et al., 19924 M. G. Lockley, J. Holbrook, A. P. Hunt, M. Matsukawa, and C. G. Meyer, The dinosaur freeway: A preliminary report on the Cretaceous megatracksite, Dakota Group, Rocky Mountain Front Range and Highplains; Colorado, Oklahoma and New Mexico. In: R. Flores, Editor, Mesozoic of the Western Interior. SEPM Midyear Meeting Fieldtrip Guidebook (1992), pp. 39-54.

Lockley et al., 2006 M. G. Lockley, J. Holbrook, R. Kukihara, and M. Matsukawa, An Ankylosaur-dominated dinosaur tracksite in the Cretaceous Dakota Group of Colorado: paleoenvironmental and sequence stratigraphic context. In: S. G. Lucas and R. M. Sullivan, eds., Late Cretaceous Vertebrates from the Western Interior, New Mexico Museum of Natural History and Science Bulletin vol. 35 (2006), pp. 95-104.

Lohmann, 19884 K. C. Lohmann, Geochemical patterns of meteoric diagenetic systems and their application to stud- ies of paleokarst. In: N. P. James and P. W. Choquette, eds., Paleokarst, Springer-Verlag, New York (1988), pp. 58-80.

Lucas et al., $2000<$ S. G. Lucas, A. B. Heckert, and R. M. Sullivan, Cretaceous Dinosaurs in New Mexico. New Mexico Museum of Natural History and Science Bulletin, vol. 17 (2000), pp. 83-90.

Ludvigson et al., 1996 G. A. Ludvigson, L. A. González, B. J. Witzke, R. L. Brenner, and R. A. Metzger, Diagenesis of iron minerals in the Dakota Formation. In: B. J. Witzke and G. A. Ludvigson, eds., Mid-Cretaceous Fluvial Deposits of the Eastern Margin, Western Interior Basin: Nishnabotna Member, Dakota Formation, Iowa Geological Survey Bureau Guidebook Series, vol. 17 (1996), pp. 31-38.

Ludvigson et al., 1998 G. A. Ludvigson, L. A. González, R. A. Metzger, B. J. Witzke, R. L. Brenner, A. P. Murillo, and T. S. White, Meteoric sphaerosiderite lines and their use for paleohydrology and paleoclimatology, Geology 26 (1998), pp. 1039-1042.

Matsukawa et al., 19994 M. Matsukawa, M. G. Lockley, and A. P. Hunt, Three age groups of ornithopods inferred from footprints in the mid-Cretaceous Dakota Group, eastern Colorado, North America, Palaeogeogr. Palaeoclimatol. Palaeoecol. 147 (1999), pp. 39-51.

McCarthy and Plint, $1999 \varangle$ P. J. McCarthy and A. G. Plint, Floodplain paleosols of the Cenomanian Dunvegan Formation, Alberta and British Columbia, Canada: Micromorphology, pedogenic processes, and paleoenvironmental implications. In: S. B. Marriott and J. Alexander, eds., Floodplains: Interdisciplinary Approaches, Geol. Soc. Amer. Sp. Pap., vol. 163 (1999), pp. 289-310.

Moore, 19994 W. S. Moore, The subterranean estuary: A reaction zone of ground water and sea water, Mar. Chem. 65 (1999), pp. 111-125.

Munter et al., 1983 J. A. Munter, G. A. Ludvigson, and B. J. Bunker, Hydrogeology and stratigraphy of the Dakota Formation in northwest Iowa, Iowa Geol. Surv., Water-Supply Bull. 13 (1983).

Paik et al., 2001 I. S. Paik, H. J. Kim, and Y. I. Lee, Dinosaur track-bearing deposits in the Cretaceous Jindong Formation, Korea: Occurrence, palaeoenvironments and preservation, Cretaceous Res. 22 (2001), pp. 77-92.

Plummer and Romary, $1942<$ N. V. Plummer and J. F. Romary, Stratigraphy of the pre-Greenhorn Cretaceous beds of Kansas, Kansas Geol. Surv. Bull. 41 (1942), pp. 313-348.

Pryor, 19734 W. A. Pryor, Permeability-porosity patterns and variations in some Holocene sand bodies, AAPG Bull. 57 (1973), pp. 162-189.

Ravn and Witzke, $1995 \varangle$ R. L. Ravn and B. J. Witzke, The palynostratigraphy of the Dakota Formation (?Late Albian-Cenomanian) in its type area, northwestern Iowa and northeastern Nebraska, USA, Palaeontogr., Abt. B 234 (1995), pp. 93-171.

Rozanski et al., 1993 K. Rozanski, L. Araguas-Araguas, and R. Gonfiantini, Isotopic patterns in modern global precipitation. In: P. K. Swart, K. C Lohman, J. A. McKenzie and S. Savin, eds., Climate Change in Continental Isotope Records, Am. Geophys. Union Geophys. Mono., vol. 78 (1993), pp. 1-36.

Scott et al., $1998 \varangle$ R. W. Scott, P. C. Franks, M. J. Evetts, J. A. Bergen, and F. A. Stein, Timing of mid-Cretaceous relative sea level changes in the Western Interior: Amoco No. 1 Bounds core. In: W. E. Dean and M. A. Arthur, eds., Stratigraphy and Paleoenvironments of the Cretaceous Western Inte- 
rior Seaway, USA, SEPM Concepts in Sedimentology and Paleontology, vol. 6 (1998), pp. 11-34.

Seilacher, 1967 A. Seilacher, Bathymetry of trace fossils, Mar. Geol. 5 (1967), pp. 413-428.

Spicer and Corfield, $1992<$ R. A. Spicer and R. M. Corfield, A review of terrestrial and marine climates in the Cretaceous with implications for modelling the 'Greenhouse Earth', Geol. Mag. 129 (1992), pp. 169-180.

Stolt et al., 1994 M. H. Stolt, C. M. Ogg, and J. C. Baker, Strongly contrasting redoximorphic patterns in Virginia valley and ridge paleosols, Soil Sci. Soc. Am. J. 58 (1994), pp. 477-484.

Stoops, $1983 \varangle$ G. Stoops, SEM and light microscope observations of minerals in bog ores of the Belgium Campine, Geoderma 30 (1983), pp. 179-186.

Swart et al., $1993<$ P. K. Swart, J. A. McKenzie, and K. C. Lohmann, Introduction. In: P. K. Swart, K. C Lohmann, J. A. McKinzie and S. Savin, eds., Climate Change in Continental Isotopic Records, Am. Geophys. Union Geophys. Mono, vol. 78 (1993), pp. xi-xiii.

Taylor et al., $2000 \varangle$ K. G. Taylor, R. L. Gawthorpe, C. D. Curtis, J. D. Marshall, and D. N. Awwiller, Carbonate cementation in a sequence-stratigraphic framework: Upper Cretaceous sandstones, Book Cliffs, Utah-Colorado, J. Sediment. Res. 70 (2000), pp. 360-372.

Thomas et al., 19874 R. G. Thomas, D. G. Smith, J. M. Wood, J. Visser, E. A. Calverley-Range, and E. H. Koster, Inclined heterolithic stratification - Terminology, description, interpretation and significance, Sediment. Geol. 53 (1987), pp. 123-179.

Tucker, 1981 M. E. Tucker, Sedimentary Petrology - An Introduction, Blackwell Scientific Publications, Oxford (1981).

Ufnar et al., 2002 D. F. Ufnar, L. A. González, G. A. Ludvigson, R. L. Brenner, and B. J. Witzke, The mid-Cretaceous water bearer: isotope mass balance quantification of the Albian hydrologic cycle, Palaeogeogr. Palaeoclimatol. Palaeoecol. 188 (2002), pp. 51-71.

Vepraskas, 1994 M. J. Vepraskas, Redoximorphic features for identifying aquatic conditions, Carolina Agri. Res. Surv., Tech. Bull. 30 (1994).

Weimer, $1988<$ R. J. Weimer, Sequence stratigraphy and paleotectonics, Denver Basin area of Lower Cretaceous foreland basin, USA. In: R. N. Ginsburg and B. Deaudoin, eds., Cretaceous Resources, Events and Rhythms, NATO ASI Series C, vol. 304, Kluwer Academic Publishers (1988), pp. 23-32.
White et al., $2000<$ T. S. White, B. J. Witzke, and L. A. Ludvigson, Evidence for an Albian Hudson arm connection between the Cretaceous Western Interior Seaway of North America and the Labrador Sea, Geol. Soc. Amer. Bull. 112 (2000), pp. 1342-1355.

White et al., 20014 T. S. White, L. A. González, G. A. Ludvigson, and C. J. Poulsen, Middle Cretaceous greenhouse hydrologic cycle of North America, Geology 29 (2001), pp. 363-366.

Whitley, $1980 \backsim$ D. L. Whitley, A stratigraphic and sedimentologic analysis of Cretaceous rocks in northwest Iowa. M.S. Thesis, University of Iowa, Iowa City, USA, 1980.

Whitley and Brenner, 19814 D. L. Whitley and R. L. Brenner, Subsurface stratigraphic and sedimentologic analyses of Cretaceous rocks in northwest Iowa. In: R. L. Brenner, R. F. Bretz, B. J. Bunker, D. L. Iles, G. A. Ludvigson, R. M. McKay, D. L. Whitley and B. J. Witzke, eds., Cretaceous Stratigraphy and Sedimentation in Northwest Iowa, Northeast Nebraska, and Southeast South Dakota, Iowa Geological Survey, Guidebook Series, vol. 4 (1981), pp. 57-75.

Witzke and Ludvigson, 1994 B. J. Witzke and G. A. Ludvigson, The Dakota Formation in Iowa and the type area. In: G. W. Shurr, G. A. Ludvigson and R. H. Hammond, eds., Perspectives on the Eastern Margin of the Cretaceous Western Interior Basin KWIS, Geol. Soc. Am. Spec. Pap., vol. 287 (1994), pp. 43-78.

Witzke et al., 1983 B. J. Witzke, G. A. Ludvigson, J. R. Poppe, and R. L. Ravn, Cretaceous paleogeography along the eastern margin of the Western Interior Seaway, Iowa, southern Minnesota, and eastern Nebraska and South Dakota. In: M. W. Reynolds and E. D. Dolly, eds., Mesozoic Paleogeography of West-Central United States: Rocky Mountain Paleogeography Symposium, vol. 2, Rocky Mountain Section SEPM, Denver, CO (1983), pp. 225-252.

Wolfe and Upchurch, 1987 J. A. Wolfe and G. R. Upchurch Jr., North American nonmarine climates and vegetation during the Late Cretaceous, Palaeogeogr. Palaeoclimatol. Palaeoecol. 61 (1987), pp. 33-77.

Wright, 19864 V. P. Wright, Pyrite formation and the drowning of a palaeosol, Geol. J. 21 (1986), pp. 139-149.

Young, 20024 L. D. Young, High resolution chemostratigraphic correlations and the development of accommodation space, in mid-Cretaceous strata, eastern margin Western Interior Seaway, Central United States. M.S. Thesis, University of Iowa, Iowa City, USA, 2002. 